\title{
Provenance and paleogeography of post-Middle Ordovician, pre-Devonian sedimentary basins on the Gander composite terrane, eastern and east-central Maine: implications for Silurian tectonics in the northern Appalachians
}

\author{
Allan Ludman ${ }^{1}$, JOHn HopeCK², AND Henry N. BERry IV ${ }^{3}$ \\ 1. School of Earth and Environmental Sciences, Queens College (CUNY), Flushing, New York 11367, USA \\ 2. Maine Department of Environmental Protection 17 State House Station, \\ Augusta, Maine 04333, USA \\ 3. Maine Geological Survey, 93 State House Station, Augusta Maine 04333, USA \\ *Corresponding author <allan.ludman@qc.cuny.edu>
}

Date received: 02 May 2016 Date accepted: 29 December 2016

\begin{abstract}
Recent mapping in eastern and east-central Maine addresses long-standing regional correlation issues and permits reconstruction of post-Middle Ordovician, pre-Devonian paleogeography of sedimentary basins on the Ganderian composite terrane. Two major Late Ordovician-Silurian depocenters are recognized in eastern Maine and western New Brunswick separated by an emergent Miramichi terrane: the Fredericton trough to the southeast and a single basin comprising the Central Maine and Aroostook-Matapedia sequences to the northwest. This Central Maine/Aroostook-Matapedia (CMAM) basin received sediment from both the Miramichi highland to the east and highlands and islands to the west, including the pre-Late Ordovician Boundary Mountains, Munsungun-Pennington, and Weeksboro-Lunksoos terranes. Lithofacies in the Fredericton trough are truncated and telescoped by faulting along its flanks but suggest a similar basin that received sediment from highlands to the west (Miramichi) and east (St. Croix).

Deposition ended in the Fredericton trough following burial and deformation in the Late Silurian, but continued in the CMAM basin until Early Devonian Acadian folding. A westward-migrating Acadian orogenic wedge provided a single eastern source of sediment for the composite CMAM basin after the Salinic/Early Acadian event, replacing the earlier, more local sources. The CMAM, Fredericton, and Connecticut Valley-Gaspé depocenters were active immediately following the Taconian orogeny and probably formed during extension related to post-Taconian plate adjustments. These basins thus predate Acadian foreland sedimentation.

Structural analysis and seismic reflection profiles indicate a greater degree of post-depositional crustal shortening than previously interpreted. Late Acadian and post-Acadian strike-slip faulting on the Norumbega and Central Maine Boundary fault systems distorted basin geometries but did not disturb paleogeographic components drastically.
\end{abstract}

\section{RÉSUMÉ}

Une récente cartographie de l'est et du centre-est du Maine aborde des questions de longue date concernant la corrélation régionale et permet de reconstruire la paléogéographie des bassins sédimentaires de la période postérieure à l'Ordovicien moyen et antérieure au Dévonien sur le terrane composite du Gandérien. Deux dépocentres majeurs de la période allant de l'Ordovicien tardif au Silurien sont constatés dans l'est du Maine et dans l'ouest du Nouveau-Brunswick, séparés par le terrane émergent de Miramichi : la dépression de Fredericton au sud-est et un bassin unique comprenant les séquences du centre du Maine et d’Aroostook-Matapédia au nord-ouest. Ce bassin du centre du Maine et d'Aroostook-Matapédia (CMAM) a reçu des sédiments des hautes terres de Miramichi à l'est et des hautes terres et des îles à l'ouest, incluant les terranes du mont Boundary, de Munsungun-Pennington et de Weeksboro-Lunksoos de la période antérieure à l'Ordovicien tardif. Les lithofaciès dans la dépression de Fredericton sont tronqués et repliés par la formation de failles le long de ses flancs, mais ils suggèrent la présence d'un bassin similaire ayant reçu des sédiments des hautes terres à l'ouest (Miramichi) et à l'est (St. Croix).

Le dépôt s'est terminé dans le bassin de Fredericton à la suite des périodes d'enfouissement et de déformation du Silurien tardif, mais il a continué dans le bassin du CMAM jusquà la formation des plis acadiens du Dévonien précoce. 
Un prisme orogénique acadien migrant vers l'ouest a fourni une seule source de sédimentation à l'est pour le bassin composite du CMAM après l'événement salinique ou la phase acadienne précoce, remplaçant les sources antérieures plus locales. Les dépocentres du CMAM, de Fredericton et de Connecticut Valley-Gaspé étaient actifs immédiatement après l'orogénie du Taconien et se sont probablement formés durant l'extension liée aux ajustements de plaques postérieurs au Taconien. Ces bassins précèdent donc la sédimentation dans les avant-pays de l’Acadien.

Lanalyse structurale et les profils de réflexion sismique indiquent un degré plus élevé de rétrécissement de la croûte postérieur au processus de sédimentation que l'interprétation antérieure. Le mouvement de coulissage de l'Acadien tardif et postérieur à l'Acadien sur les systèmes de failles de Norumbega et de la région frontalière du centre du Maine ont déformé la géométrie des bassins, mais n’ont pas beaucoup perturbé les éléments paléogéographiques.

[Traduit par la redaction]

\section{INTRODUCTION}

The Paleozoic history of the northern Appalachians was punctuated by several orogenic events as the three outboard microplates of the Gondwanan Realm (Fig. 1) accreted progressively to ancestral North America (Laurentia) during closure of the Iapetus Ocean. This paper focuses on a relatively quiet interval from Late Ordovician (Ashgill) to Late Silurian times when an enormous volume of sediment eroded from post-Middle Ordovician highlands was deposited in extensive basins on the Ganderian composite plate. Today, tracts of the older rocks are separated by these younger basin-fill sediments (Fig. 2).

This paper approaches tectonic interpretation from a perspective different from most others, reading the record of tectonic events preserved in post-Taconian, pre-Acadian cover rock sediments of these basins. The lack of detailed mapping in eastern and east-central Maine, an area where complex deformation overprints complex stratigraphy, has frustrated attempts to correlate strata in these basins and decipher their evolution. This paper fills many of the critical gaps and is based on 35 years of mapping in the area outlined in Figure 2. We present an updated geologic map (Fig. 3) containing major changes from the most recent Maine bedrock map (Osberg et al. 1985) and a new regional correlation of Late Ordovician-Late Silurian cover rocks from the Central Maine, Aroostook-Matapedia, and Fredericton sequences. These advances, together with recognition of the importance of faulting in regional tectonism, lead to a refined model of Ganderian terranes as sediment sources for the intervening cover sequences, aid in interpreting Late Ordovician-Silurian paleogeography, and suggest roles of the Cambrian-Ordovician terranes during Salinic and later Acadian deformation.

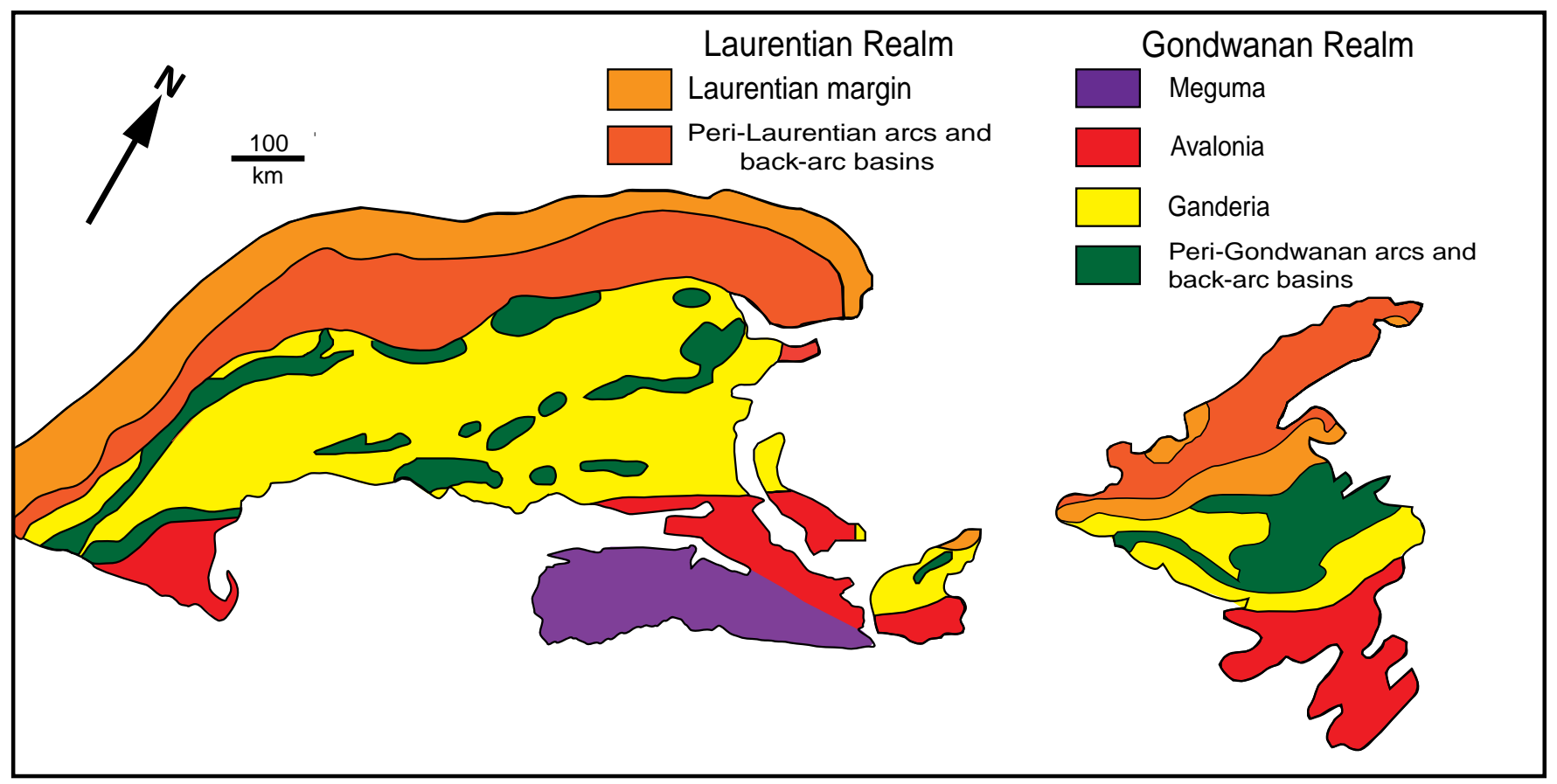

Figure 1. Lithotectonic divisions of the New England and Maritime Appalachians (after Hibbard et al. 2006). 


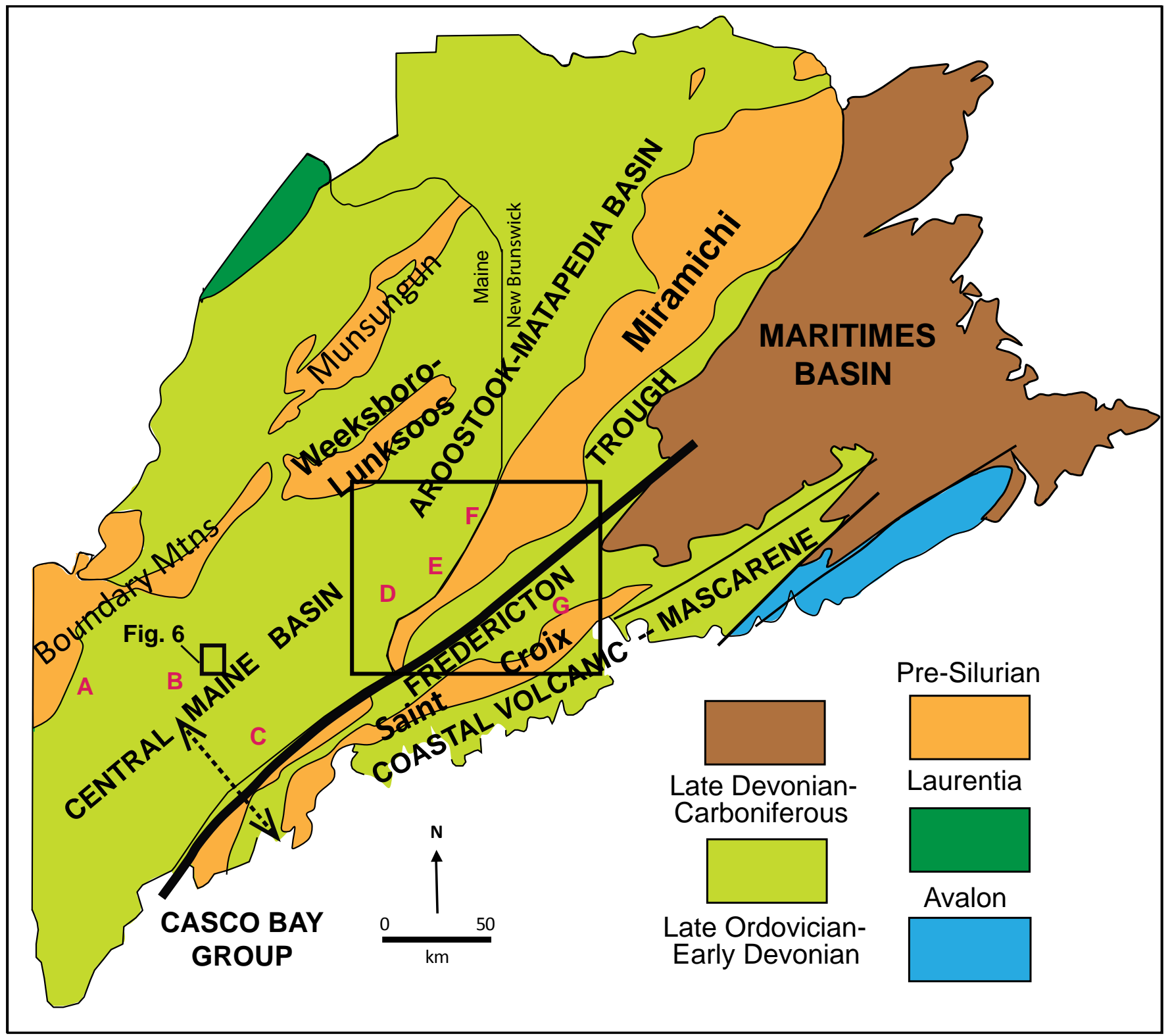

Figure 2. Late Ordovician - Early Devonian cover rocks and pre-Late Ordovician terranes of Maine and New Brunswick (after Osberg et al. 1985, and New Brunswick Department of Natural Resources and Energy 2000). Large rectangle outlines area of Figure 3. Letters show locations of stratigraphic columns in Table 2. Double arrow shows Rome-Camden transect of Tucker et al. (2001) shown in Figure 10.

\section{Geologic setting}

The northern Appalachian orogen widens dramatically to the north from the deep-crustal, high-grade metamorphic region of southern New England to shallow crustal lowgrade rocks in eastern Maine and New Brunswick (Fig. 1). Maine contains the broadest expanse of the Ganderian composite plate in New England, with several CambrianOrdovician terranes occurring as inliers within blanketing Late Ordovician through Early Devonian cover rock sequences. The study area outlined in Figure 2 contains portions of the Coastal Volcanic-Mascarene, Fredericton, Central Maine, and Aroostook-Matapedia cover sequences.
This paper focuses on relationships of the last three with their neighboring Cambrian-Ordovician St. Croix, Miramichi, and Weeksboro-Lunksoos Lake Ganderian terranes.

All strata in the study area experienced chlorite and subchlorite grade regional metamorphism, with more intense recrystallization only in contact aureoles surrounding granitic and mafic plutons. Primary depositional features are generally well preserved but bedding is masked in some pelitic and calcareous units by one or more generations of transposed layering. Despite their low regionalmetamorphic grade, the Late Ordovician to Early Devonian cover strata record multi-phase deformation including episodes of 


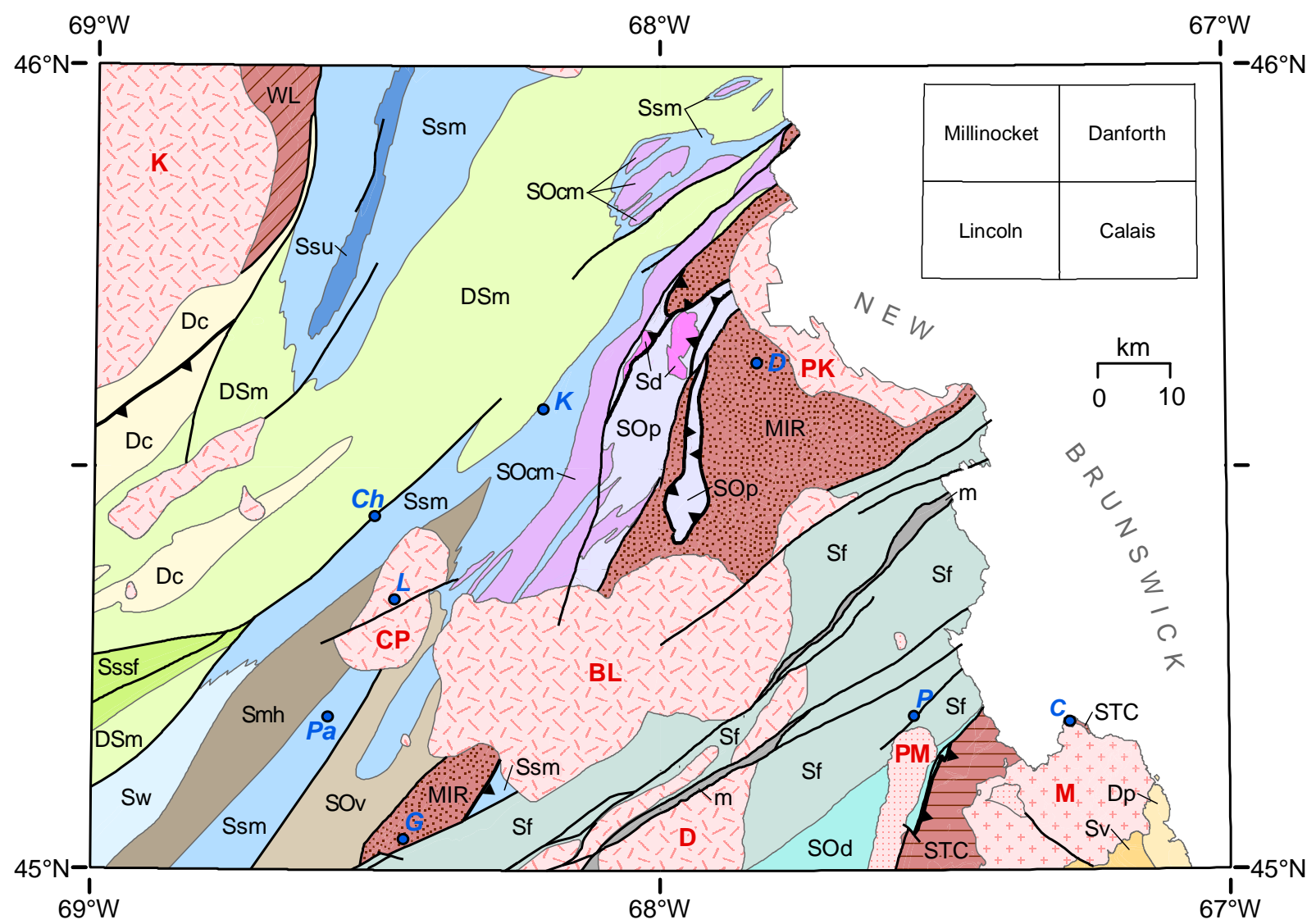

\section{EXPLANATION}

Central Maine Basin, intermediate facies

\begin{tabular}{|c|l}
\cline { 1 - 1 } Dc & Carrabassett Fm. \\
\cline { 1 - 1 } DSm & Madrid Fm. \\
\cline { 1 - 1 } Sssf & $\begin{array}{l}\text { Sangerville through } \\
\text { Smalls Falls F ms. }\end{array}$ \\
\cline { 1 - 2 } &
\end{tabular}

Central Maine Basin, distal facies

\begin{tabular}{|c|l}
\hline Smh & Mayflower Hill Fm. \\
\cline { 1 - 1 } Sw & Waterville $\mathrm{Fm}$. \\
\hline SOv & Vassalboro G $\mathrm{p}$. , undiff.
\end{tabular}

Aroostook-Matapedia Basin, distal facies

\begin{tabular}{ll}
\cline { 1 - 1 } $\mathrm{Ssm}$ & Smyrna Mills $\mathrm{Fm}$. \\
\cline { 1 - 2 } $\mathrm{Ssu}$ & Unnamed sandstone \\
\cline { 1 - 2 } $\mathrm{SO \textrm {cm }}$ & Carys Mills $\mathrm{Fm}$.
\end{tabular}

Aroostook-Matapedia Basin, proximal/intermediate facies

$\mathrm{Sd}$ Daggett Ridge $\mathrm{Fm}$.

sop Prentiss Group, undiff.

\section{Fredericton Trough}

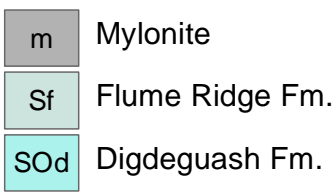

\section{Coastal Belt}

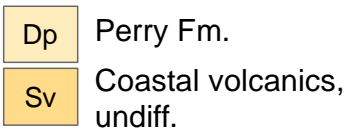

Plutons

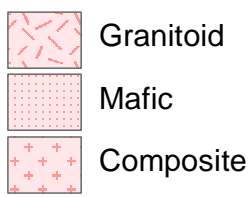

Pre-Late Ordovician terranes

WLI Weeksboro-Lunksoos Lake
MIR Miramichi
STE- St. Croix

Faults

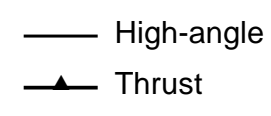

Figure 3. Simplified bedrock geology of eastern and east-central Maine (after Ludman and Hopeck 2011). Inset shows location of 1:100 000-scale sheets. Towns (in blue): $\mathrm{C}=$ Calais; $\mathrm{Ch}=$ Chester; $\mathrm{D}=$ Danforth; $\mathrm{G}=$ Greenfield; $\mathrm{K}=$ Kingman; $\mathrm{L}=$ Lincoln; $\mathrm{Pa}=$ Passadumkeag $\mathrm{P}=$ Princeton. Plutons (in red): $\mathrm{K}=$ Katahdin; $\mathrm{CP}=$ Center Pond; $\mathrm{PK}=$ Pokiok; $\mathrm{D}=$ Deblois; $\mathrm{BL}=$ Bottle Lake complex; $\mathrm{PM}=$ Pocomoonshine; $\mathrm{M}=$ Moosehorn complex. Designation of SOv for sandstones of uncertain position relative to the Waterville Formation follows Marvinney et al. 2010. 
recumbent and upright folding, and thrust, strike-slip and high-angle dip-slip faulting. Precise ages and correlation are uncertain for most of the cover sequence formations because of their lithologic similarities and the almost total absence of fossils. Correlation and lithofacies analyses are further hindered by extensive glacial deposits that limit bedrock exposures to less than $1 \%$ of the study area.

\section{Tectonic context}

Many plate tectonic models have been proposed for the northern Appalachians, starting with the pioneering work of Bird and Dewey (1970), and followed by a steady stream of papers by various workers (e.g., Osberg 1978; Bradley 1983; Osberg et al. 1989; Stewart et al. 1993; van Staal 1994; Tucker et al. 2001; van Staal et al. 2009; Hibbard et al. 2010; Fyffe et al. 2011; Reusch and van Staal 2012; Llamas and Hepburn 2013). These models differ in significant details such as the number and polarity of subduction zones and geodynamic relationships, but generally agree on the plate accretion and orogenic sequence shown in Table 1. However, Bradley et al. (2000) considered the Salinic, Acadian, and Neoacadian events to be phases of a diachronous Acadian orogeny.

Bradley et al. (2000) presented a comprehensive analysis of syn-Acadian sedimentation in Maine from Late Silurian through Middle Devonian time, proposing a dramatic change in the sedimentary regime during the interval explored in this paper. They documented diachronous deposition across the state in a NW-migrating Acadian foreland basin fed by sediment from an actively deforming orogenic wedge to the east that covered the older Late Ordovician - Middle Silurian strata derived from more varied local sources.

Post-Acadian plate adjustments in the study area were localized along the regional Norumbega fault system (Ludman and West 1999 and included papers) and the Chester shear zone (Ludman 2010). Faulting began around $380 \mathrm{Ma}$ in both (Ludman et al. 1999; West 1999; Ghanem et al. 2016), and some Norumbega fault strands were reactivated several times in the late Paleozoic (Wang and Ludman 2002, 2004). Apatite fission-track studies indicate that the latest activity in the Norumbega system appears to have been as recent as late Mesozoic time (West and RodenTice 2003). Although Norumbega faulting distorted basin geometry and obscures basin/source relationships, it did not juxtapose far-traveled lithotectonic blocks (Ludman 1981; Osberg et al. 1989; Bradley et al. 2000).

\section{Revised geologic map}

The study area was one of the least-studied parts of Maine at the time the most recent state bedrock map (Osberg et al. 1985) was compiled, its geology based largely on reconnaissance mapping (Larrabee et al. 1965; Ludman, unpublished data). New correlations and improved structural understanding summarized in Figure 3 are based on our work since 1985 in four 1:100 000-scale quadrangles (Fig. 3 inset) of which only the Calais sheet has been mapped fully in detail (Ludman and Berry 2003).

Table 1. Tectonic evolution of the Northern Appalachians (modified after Hibbard et al . 2006; Hatcher 2010; Fyffe et al . 2011;

Ghanem et al. 2016).

\begin{tabular}{|c|c|c|}
\hline AGE & OROGENIC EVENT & PLATE TECTONIC EXPLANATION \\
\hline Permian & Alleghanian & Accretion of Gondwana to previously amalgamated plates \\
\hline Late Devonian & "Neoacadian" & Accretion of Meguma to previously amalgamated plates \\
\hline Early Devonian & Acadian & Accretion of Avalon to previously amalgamated plates \\
\hline Late Silurian & Salinic & Closure of remnant back-arc basin and amalgamation of Ganderia with Laurentia \\
\hline $\begin{array}{l}\text { Early Devonian- } \\
\text { Late Ordovician }\end{array}$ & & Time Span Covered in this Paper \\
\hline $\begin{array}{l}\text { Mid-Ordovician } \\
\text { (Caradocian) }\end{array}$ & Taconian & Accretion of leading edge of Ganderian composite plate to Laurentia \\
\hline $\begin{array}{l}\text { Cambrian - } \\
\text { Ordovician }\end{array}$ & Penobscot & Amalgamation of Ganderian microplates within the Iapetus Ocean \\
\hline Latest Neoproterozoic & & Rifting of Rodinian supercontinent, open of Iapetus Ocean \\
\hline $\begin{array}{l}\text { Late Neoproterozoic } \\
\qquad(\sim 1 \mathrm{Ga})\end{array}$ & Grenville & Assembly of Rodinian supercontinent \\
\hline
\end{tabular}




\section{PRESERVED POST-MIDDLE ORDOVICIAN, PRE-DEVONIAN LITHOFACIES RELATIONSHIPS}

Faults today separate most cover rock basins in our study area from adjacent pre-Late Ordovician terranes and obscure direct lithofacies evidence for sedimentsource relationships. The following sections discuss improved understanding of the Central Maine, AroostookMatapedia, and Fredericton stratigraphic sequences based on work in areas previously known mostly from reconnaissance studies. The new information addresses long-standing issues of correlation, relationships among the basins in which these sequences were deposited, basin symmetry or asymmetry, and the role of the Miramichi terrane as a sediment source. It also questions commonly accepted interpretations of facies relationships in the axial region of the Central Maine depocenter (e.g., Pankiwskyj et al. 1976) and the role of the pre-Late Ordovician terranes in controlling local deformation. Table 2 summarizes our interpreted correlation of post-Middle Ordovician cover sequences in eastern and east-central Maine and suggests correlation with those of the western and central parts of the state.

A cautionary note: Interpreting modern lithofacies in orogenically active deep-sea environments is challenging but doing so in polydeformed Paleozoic terranes is far more difficult, especially where bedrock comprises less than $1 \%$ of the surface area. Channels incised into modern submarine fans juxtapose quite different lithologies locally and syndepositional slumping and deformation may disrupt large packages of sediment. Interpretations presented in this section are of necessity based on relationships among units hundreds to thousands of meters thick that are exposed over large parts of the basins in which they were deposited and, therefore, have the best chance to preserve original sedimentologic associations.

\section{“Central Maine basin”}

The Central Maine basin is a major component of the northern Appalachians, extending from central Maine ostensibly to Long Island Sound (Hibbard et al. 2006). Several studies beginning in the 1960s and 1970s showed that the pre-Silurian Bronson Hill-Boundary Mountains terrane had shed sediment southeastward into the basin starting in Late Ordovician time and proposed a proximalto-distal facies transition extending from western Maine to the Waterville area of central Maine (Osberg et al. 1968, 1988; Ludman 1969; Ludman and Griffin 1974; Pankiwskyj et al. 1976; Moench and Pankiwskyj 1988).

The proximal facies (Table 2, left column) was defined in western Maine (A in Fig. 2) by Moench (1971) and refined by Moench and Pankiwskyj (1988). It includes the Early Silurian Rangeley Formation, a thick, complex assemblage of very coarse to fine clastic rocks interbedded in varying proportions and with varying thicknesses with pelitic strata. Boulder and cobble conglomerates of the Rangeley Formation contain clasts derived from the adjacent pre-Late Ordovician Boundary Mountains terrane. An intermediate facies (Table 2; B on Fig. 2), generally thinner bedded and finer grained than the section near Rangeley, is present in west-central and central Maine where granule

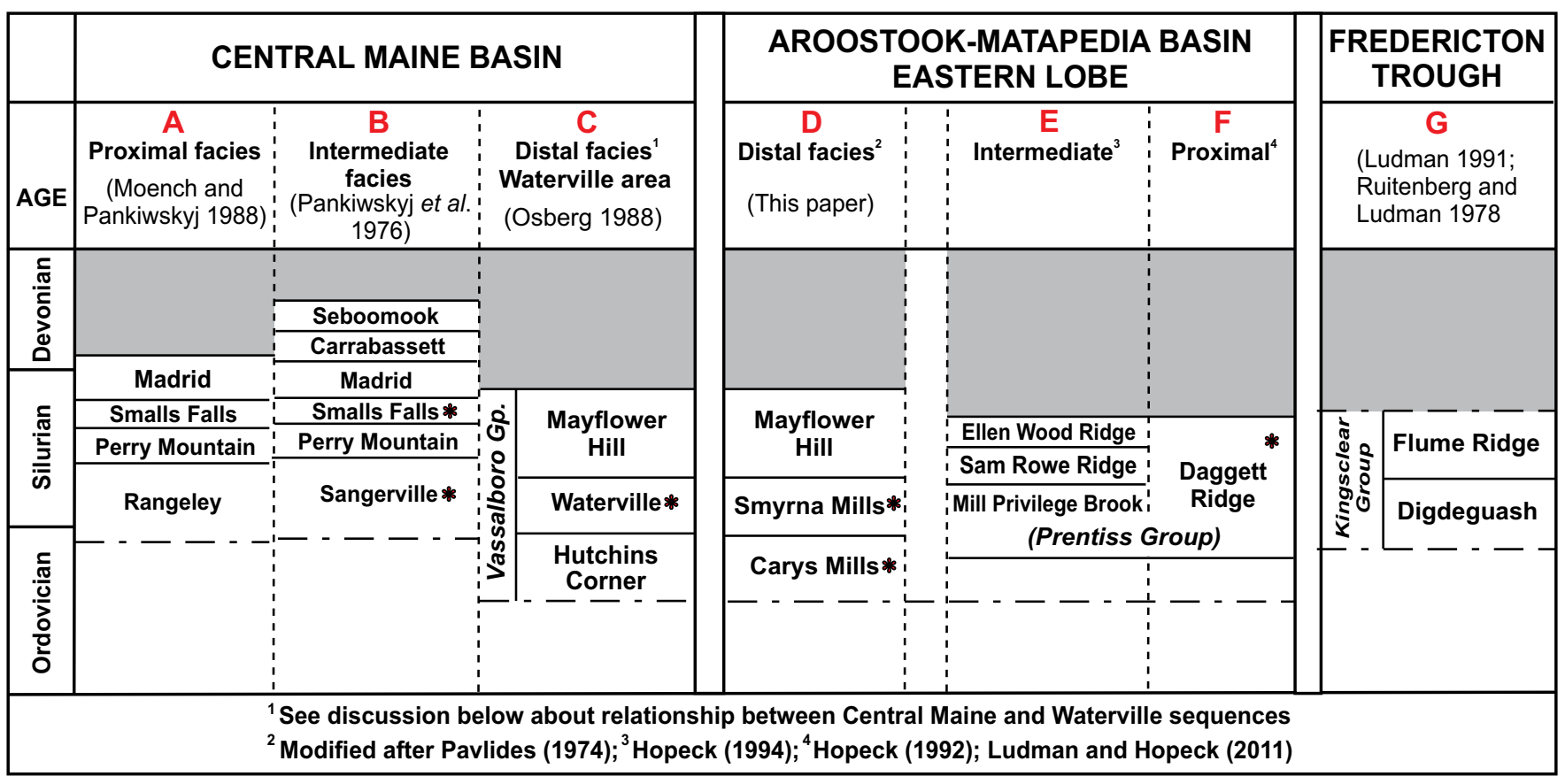

Table 2. Proposed correlation of Late Ordovician to Early Devonian basin sequences in western, central, and eastern Maine. Red letters indicate location in Figure 2. Asterisks indicate fossil age control. 
conglomerates in medium-bedded Sangerville Formation turbidites contain clasts similar to those of the Rangeley conglomerates (Ludman 1976; Pankiwskyj et al. 1976). Graptolite age control for the Llandovery-Wenlock Sangerville and Ludlow Smalls Falls formations in central Maine also constrains the ages of the intervening Perry Mountain and overlying Madrid formations (Table 2; Ludman and Griffin 1974; Pankiwskyj et al. 1976; Tucker et al. 2001). Units above the Sangerville were correlated westward through broad folds with units lying above the Rangeley Formation (Osberg et al. 1985); if this correlation is correct, the fossil-based ages for the intermediate facies would also date the proximal units.

Association of the proximal and intermediate facies with the Waterville area sequence in central Maine ( $C$ on Fig. 2)

Sparse fossil age control suggests that thin-bedded ("pinstriped"), well-graded silt-mud turbidites of the Waterville Formation are of Llandovery age and therefore at least partially temporally equivalent to the coarser grained, thicker bedded Sangerville Formation (Pankiwskyj et al. 1976; Osberg 1988). The Waterville Formation is generally considered to be the distal facies of the Central Maine basin (Ludman and Griffin 1974; Pankiwskyj et al. 1976), with the facies transition located just east of the Currier Hill syncline (Fig. 4) where atypically thin-bedded Sangerville strata were initially interpreted as interfingering with Waterville silt-mud turbidites (Ludman 1969). However, Osberg (1988) and Tucker et al. (2001) interpreted this contact to be a southeast-over-northwest thrust fault rather than a facies transition. The Lake Messalonskee thrust will be described in detail below; in this context, it is important to note here that it is one of several major west-vergent thrust faults in south-central and mid-coastal Maine that drastically telescope original depositional basins and make it difficult to determine age relationships among formations with certainty.

\section{Aroostook-Matapedia “basin”}

The Aroostook-Matapedia sequence comprising the Meduxnekeag Group (Pavlides 1968, 1971) underlies a broad area of northeastern Maine, northwestern New Brunswick, and eastern Quebec (Fig. 2), where its abundant limestone and dolostone nourish the region's potato fields. The basin has two lobes separated by the WeeksboroLunksoos Lake terrane; our work is in the southeastern lobe which extends south to and along the northwestern edge of the Miramichi terrane. The distinctive units of the Meduxnekeag Group mapped near Houlton by Pavlides $(1971,1974)$ were not reported south of our study area by Osberg et al. (1985) and relationships among rocks of the Aroostook-Matapedia sequence and those of the Central Maine and Fredericton sequences have remained elusive until the mapping reported here.

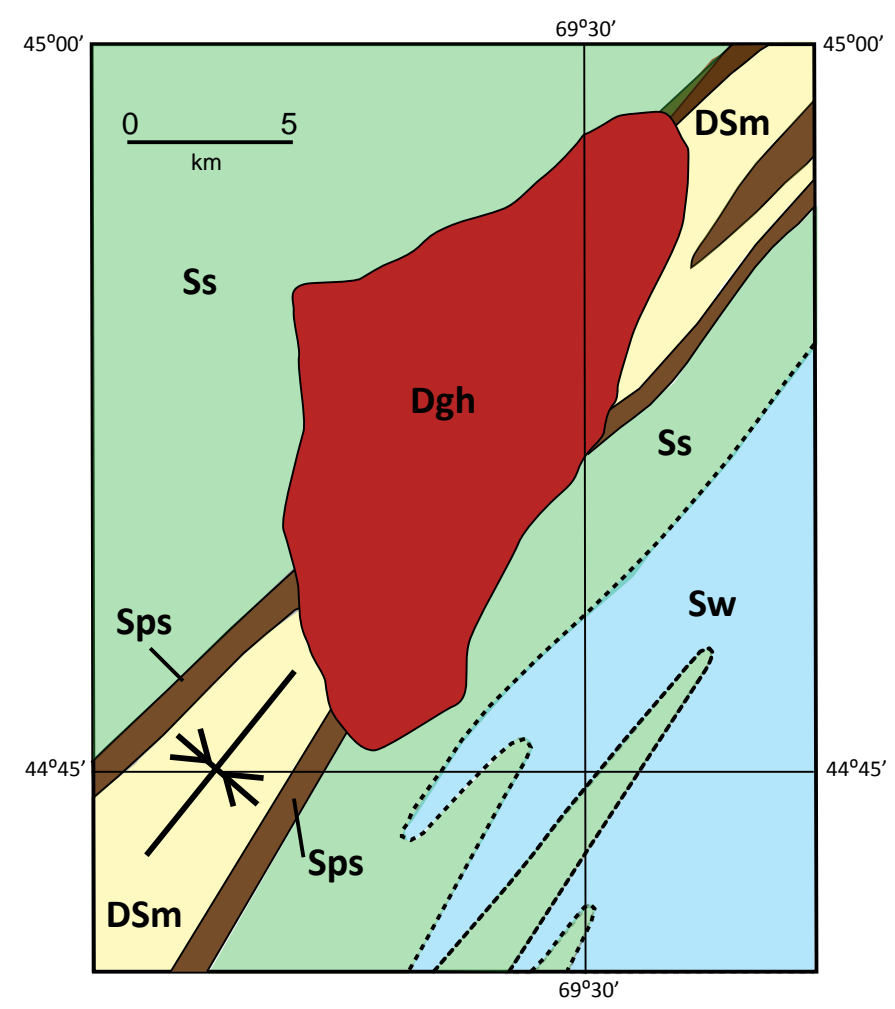

Figure 4. Sangerville/Waterville field relationships in central Maine (simplified from Osberg et al. 1985) Dashed line $=$ inferred facies change. Arrowed line $=$ Hinge surface of Currier Hill Syncline; Dgh = Hartland pluton Silurian basin fill: $\mathrm{Ss}=$ Sangerville; $\mathrm{Sw}=$ Waterville; $\mathrm{Sps}=$ Perry Mtn + Smalls Falls; DSm = Madrid. Compare with Figure 12.

The Meduxnekeag Group just north of our study area contains two very fine-grained, locally fossiliferous units (Pavlides 1971, 1974). The Late Ordovician to Early Silurian (Llandovery) Carys Mills Formation consists mostly of dark grey micritic limestone and lighter weathering dolomicrite. It passes upward gradationally into the Early to Middle Silurian (Llandovery-Wenlock) Smyrna Mills Formation, mostly thinly interbedded non-calcareous siltstone and slate with subordinate limestone horizons most abundant in the transition zone with the Carys Mills. We interpret these formations as the distal facies of the southeastern lobe of the Aroostook-Matapedia basin (Table 2).

Proximal and intermediate facies of the eastern lobe were identified adjacent to the Miramichi terrane by Hopeck (1998) who assigned them to four formations of the Prentiss Group (1998; Table 2, columns E and F; Fig. 3 Unit SOp,). Lithic clasts in boulder, cobble, pebble, and granule conglomerates of the proximal Daggett Ridge Formation were derived from Late Cambrian through Early Ordovician sedimentary and volcanic rocks of the Miramichi terrane and are also present locally in dark grey to pebble conglomerate and lithic sandstone of the Mill Privilege Brook Formation (along with black pyritiferous shale). The Mill Privilege Brook Formation may also, in part, locally underlie sections of the Daggett Ridge. 
The proximal units of the Prentiss Group pass westward into a finer grained, thinner bedded intermediate facies consisting of the Sam Rowe Ridge and Ellen Wood Ridge formations that lie above a finer grained version of the Mill Privilege Brook (Fig. 5). Strata-bound conglomerates with clasts identical to those in the proximal facies occur locally within the Sam Rowe Ridge and, more rarely, the Ellen Wood Ridge Formation. These units of the intermediate facies, in turn, interfinger to the west with the Carys Mills and Smyrna Mills formations described near Houlton (Pavlides 1971, 1974). The transition from proximal to distal facies occurs over a short distance, probably due to a combination of original basin bathymetry, depositional patterns, and tectonic shortening at the Aroostook-Matapedia/Miramichi contact discussed below.

Our mapping reveals that thick-bedded variously calcareous sandstones crop out more extensively in the northeastern part of Figure 3 than is indicated on the current Maine bedrock map (Osberg et al. 1985). Relationships of these sandstones to the Aroostook-Matapedia sequence between Houlton and Danforth have been poorly understood but a gradational contact with underlying Smyrna Mills pelites has been observed in several places in the study area (Hopeck 2013; Ludman 2013). The transition is marked locally by anomalous sulfidic, rusty-weathering sandstone at the base of the overlying sandstone or by horizons of rusty black shale and/or thinly interbedded maroon and green silt-pelite turbidites in the Smyrna Mills below.
The Smyrna Mills Formation can be traced continuously from the southwest part of the study area to the type locality of the Waterville Formation in central Maine (Fig. 4), where sandstones of the type locality Mayflower Hill Formation overlie the Waterville (Fig. 5). The Smyrna Mills and Waterville formations are therefore equivalent and the sandstones that lie conformably above the Smyrna Mills in eastern Maine are correlated with the Mayflower Hill Formation of the Vassalboro Group. There is some question about whether all the sandstones in eastern Maine can be correlated with the Mayflower Hill because some in the northern part of the study area are mapped as extensions of the Madrid Formation (Osberg et al. 1985). The Mayflower Hill and Madrid formations are similar lithologically and may be juxtaposed across the Central Maine Boundary fault, whose location is uncertain in the critical area (Figs. 3,6 ). Additional work is needed to clarify the relationships of these two sandstone units.

Axial facies changes in the Aroostook-Matapedia basin In addition to the basinward proximal-distal facies changes in the southeastern lobe, the Carys Mills and Smyrna Mills formations also exhibit systematic axial variations from northeast to southwest. The two formations, dominantly carbonate-rich and pelitic respectively, are relatively easy to distinguish north of the study area but the distinction becomes less clear southward in the central part of the Lincoln 1:100 000-scale sheet where micritic limestone and dolomicrite characteristic of the Carys Mills Formation decrease in abundance and occur as sections $\sim 50 \mathrm{~m}$ thick

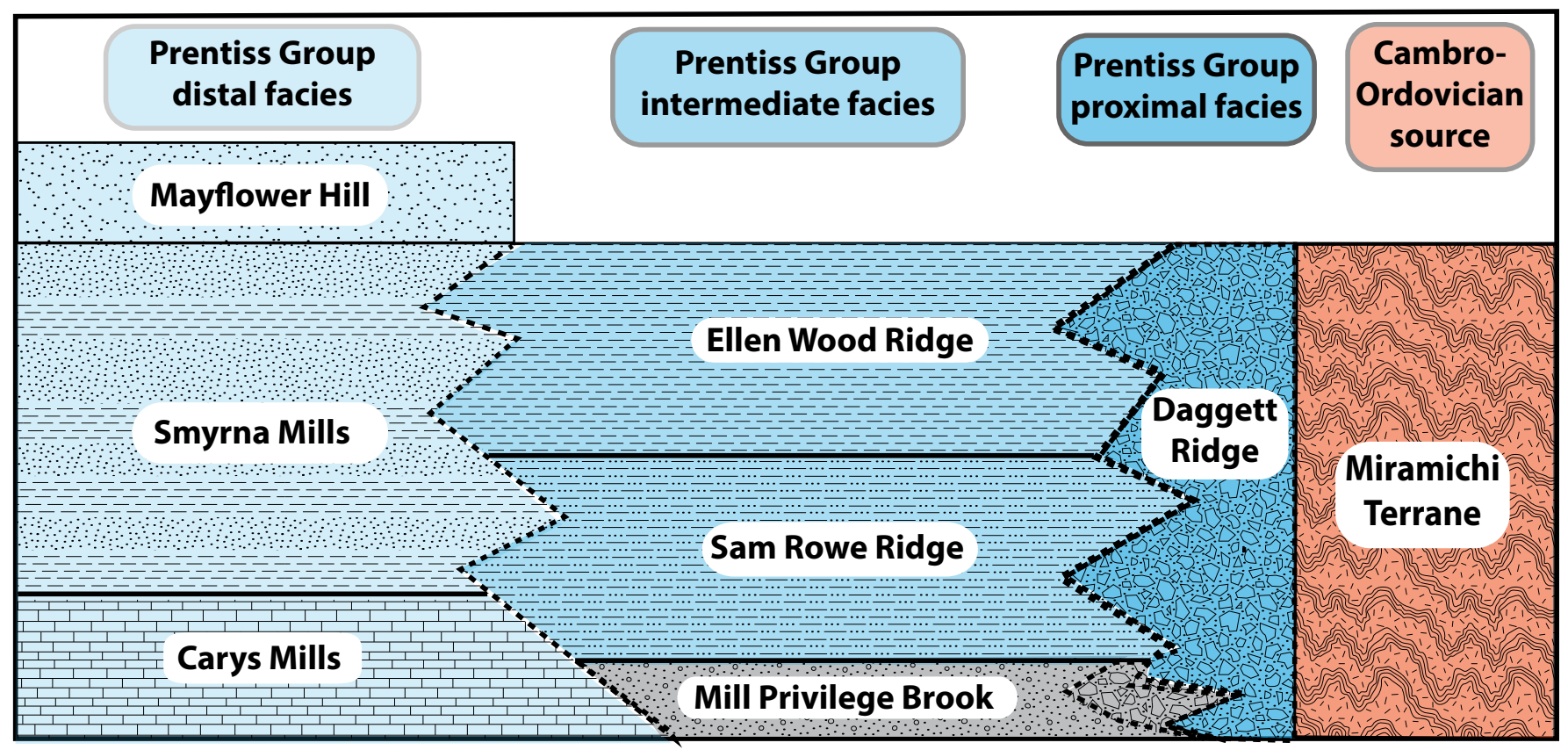

Figure 5. Facies relationships in the Aroostook-Matapedia basin eastern lobe (after Hopeck 1994 1998; Ludman 2003). 


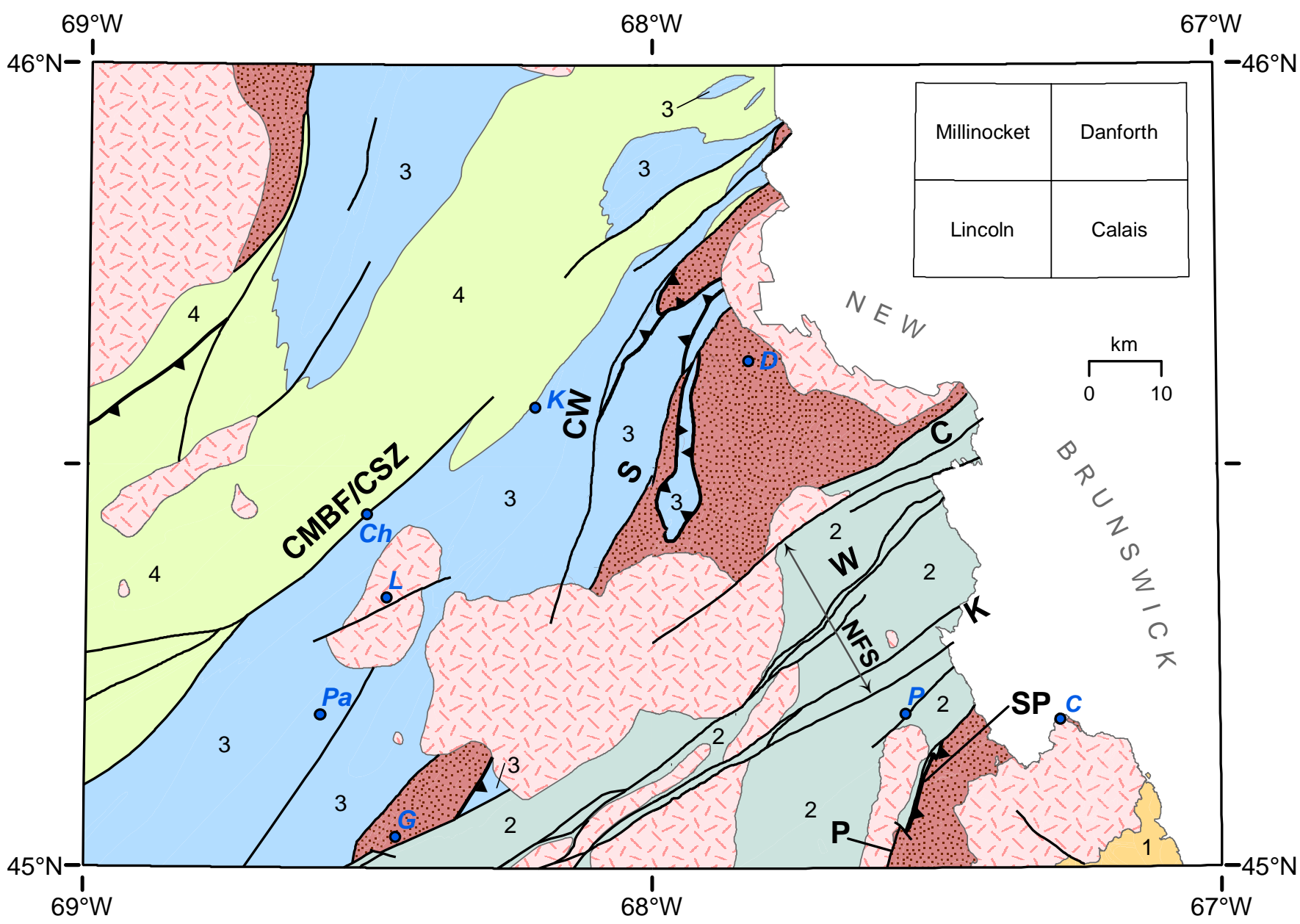

Map Units

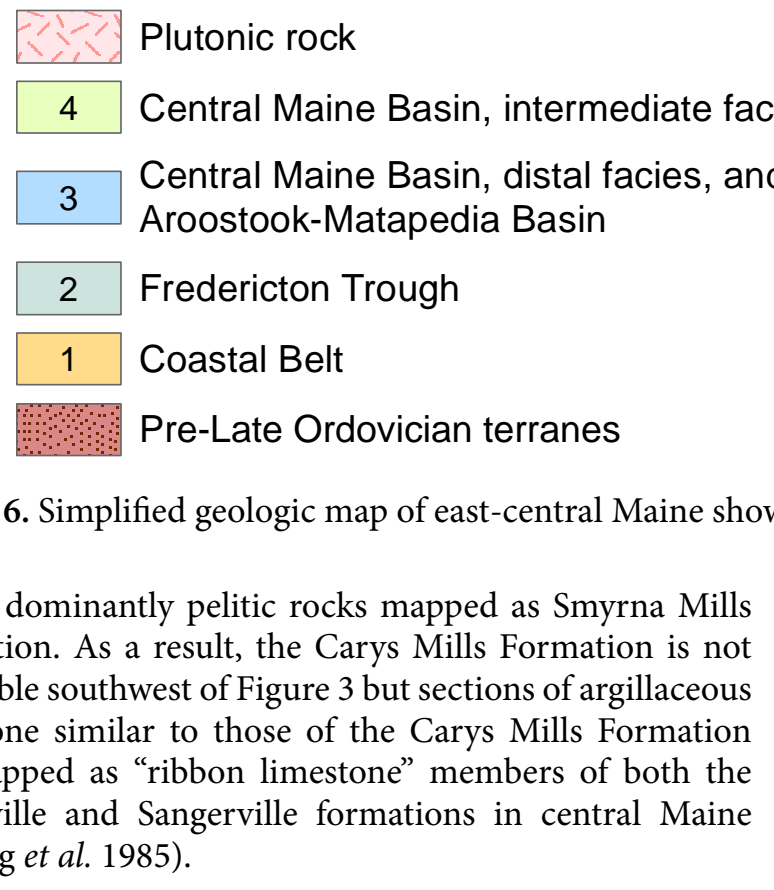

Faults

High-angle — Thrust

CMBF/CSZ - Central Maine boundary fault/ Chester shear zone

CW - Catamaran-Woodstock

$\mathbf{S}$ - S tetson Mountain Norumbega fault system (NFS)

C - Codyville

W - Waite

K - Kellyland

P - P ocomoonshine Lake

SP - South Princeton

Figure 6. Simplified geologic map of east-central Maine showing major faults. Towns (in blue) as in Figure 3.

within dominantly pelitic rocks mapped as Smyrna Mills Formation. As a result, the Carys Mills Formation is not mappable southwest of Figure 3 but sections of argillaceous limestone similar to those of the Carys Mills Formation are mapped as "ribbon limestone" members of both the Waterville and Sangerville formations in central Maine (Osberg et al. 1985).

\section{Fredericton trough}

The Fredericton trough is a prominent feature in southern New Brunswick and eastern Maine and although its mapped width narrows structurally southwest of Figure 3 , can be traced to the Casco Bay area and its rocks have been correlated with the Merrimack Group in southern Maine and New Hampshire (Fig. 2; Hussey et al. 2010). Rocks of the Fredericton trough in New Brunswick are assigned to several formations of the Kingsclear Group (Fyffe 1995), 
which are overlain unconformably by Carboniferous rocks of the Maritimes Basin (Fig. 2; New Brunswick Department of Natural Resources and Energy 2000). Thrust, high-angle dip-slip, and strike-slip faults separate the Fredericton trough from its likely Miramichi and St. Croix sources in both Canada (Fyffe 2005; Fyffe et al. 2011) and in Maine (Ludman and Berry 2003).

The Kingsclear Group in eastern Maine comprises the Digdeguash and Flume Ridge formations (G on Fig. 2 and Table 2). The Pocomoonshine Lake Formation, previously included as the oldest unit in the Fredericton trough (Ludman 1986) is now interpreted as a fault-bounded sliver with uncertain stratigraphic association. The Flume Ridge Formation occupies $85 \%$ of the Fredericton trough in Maine and is underlain to the east by the Digdeguash Formation (Fig. 3, Table 2). A unit of uncertain age on the western flank of the Fredericton trough (informally named the Buffalo Stream Formation; Ludman 2014) is here considered to be a western facies of the Flume Ridge (see below).

The Kingsclear Group in Maine is internally conformable, with a gradational contact between the Flume Ridge Formation and underlying Digdeguash Formation. Both formations exhibit partial to complete Bouma sequences indicating turbidite deposition, most probably in submarine fan complexes. The Digdeguash-Flume Ridge transition on the eastern flank of the Fredericton trough is marked by four significant changes: a rapid shift from non-calcareous to at least slightly calcareous sandstone; a decrease in grain size of the coarsest beds from granules and coarse sand to fine sand and silt; a sharp decrease in the amount of pelite (aluminous slate in D and E horizons of Digdeguash Bouma sequences is replaced by quartzofeldspathic siltstone in the Flume Ridge); and an increase in clast maturity of the coarse fraction, with typical sand-to granule-sized lithic fragments in the Digdeguash mostly giving way to monomineralic quartz and feldspar grains in the Flume Ridge.

The Flume Ridge Formation comprises variably calcareous quartzofeldspathic sandstone and siltstone with subordinate pelite typically found at the tops of graded beds. Ankerite (ferroan dolomite) grains and detrital muscovite flakes $2-5 \mathrm{~mm}$ long occur throughout the formation; weathering of the former produces a characteristic pale orange weathering rind. Attempts to subdivide the Flume Ridge Formation have been obstructed by sparse bedrock exposures and locally variable bedding styles, grain sizes, and carbonate content but there appears to be a difference between the northwestern and southeastern parts of the formation, here referred to as the western and eastern facies, respectively. Lacking fossil age control for these facies, it is not known whether the differences described below are solely geographical and helpful for paleogeographic reconstructions or might (also) be stratigraphic, reflecting a change over time.

The eastern facies, best exposed at the Kellyland dam on the St. Croix River, is generally more thinly bedded (average 10-15 cm, ranging to $25 \mathrm{~cm}$ ), more calcareous, contains more ankerite, and is finer grained than the western facies. Graded beds typically contain fine sandsized clasts that pass upward into coarse and fine silt, and in some instances, to subordinate aluminous pelite. Coarse sand clasts $(\sim 1 \mathrm{~mm})$ are present locally but are not common. Fine bed-parallel laminae and climbing ripples are present in addition to the graded bedding, but bottom features are rare. Alteration of feldspar clasts and ankerite produces a distinctive weathered appearance: a chalky white outer surface that transitions to an orange zone which sometimes completely masks the light to medium grey fresh color of the rock.

The western facies is generally thicker bedded $(15 \mathrm{~cm}$ to $>$ $1 \mathrm{~m}$ ) and coarser grained, with abundant coarse sand-sized clasts that include quartz, feldspar, and lithic fragments, mostly of very fine-grained felsic volcanic rock. Detrital white micas and diagenetic ankerite are less abundant than in the eastern facies but may be present locally. The sparse ankerite content results in a more homogeneous chalky white weathered rind. Although many beds are graded, massive coarse beds are common, in many cases exhibiting load casts and flame structures.

It is tempting to attribute the coarseness of the western facies to proximity to its source (presumably the Miramichi terrane) relative to the eastern facies, especially because volcanic clasts in latter are similar to Ordovician Miramichi tuffs in Maine. Unfortunately, uniquely Miramichi clasts like those observed in the proximal Prentiss Group on the western flank of the Miramichi terrane have not been identified in the Flume Ridge Formation.

Grain size variation in the Digdeguash Formation on the eastern flank of the Fredericton trough is similarly suggestive but not conclusive. The Digdeguash consists of variably bedded $(10 \mathrm{~cm}$ to $>2 \mathrm{~m}$ ) quartzofeldspathic and lithic wacke that occurs in homogeneous massive beds or partial to nearly complete Bouma sequences with dark grey aluminous pelite. Pelitic horizons $\sim 10-20 \mathrm{~m}$ thick are present locally. Unusually coarse (pebble) conglomerate reported by Westerman (1978) is restricted to Digdeguash exposures close to its southeastern fault contact and appears to fine gradually upward and westward, toward the center of the Fredericton trough.

Because of faulting, proximal facies comparable to those in the Central Maine and Aroostook-Matapedia sequences are absent from both flanks of the Fredericton trough (Fyffe et al. 1999) and cross-strike facies changes other than those mentioned above are not obvious. Clasts in the Flume Ridge are remarkably constant in the fine sand range across most of the Fredericton trough, but coarser (up to $1.5 \mathrm{~mm}$ ) clasts are common in lithic wacke near the western margin. Lithic clasts in Taxis River sandstone and conglomerate near the western margin of the Fredericton trough in New Brunswick were interpreted by Fyffe (1995) as having been derived from the Miramichi belt but uniquely Miramichi rocks have not been identified in the Maine strata. Bed 
thickness and carbonate content in the Flume Ridge Formation vary widely but also apparently randomly across the trough. Grain size variation in the Digdeguash Formation on the eastern flank of the Fredericton trough is similarly suggestive but not conclusive.

\section{STRUCTURAL COMPLICATIONS}

The Late Ordovician to Early Devonian cover rock sequences described above have experienced multiple deformations including Salinic and later Acadian folding and Acadian and younger faulting that create challenges for provenance studies and paleogeographic reconstructions. Crustal shortening estimates have been typically based on upright Acadian folds but poor outcrop control and insufficient key contacts preclude construction of palinspastic cross-sections (Bradley et al. 2000). Mapping and seismic reflection studies indicate that recumbent folds, thrust faults, and high-angle faults are more abundant than was shown by Osberg et al. (1985) and played important roles in early stages of Acadian tectonism. This section examines the effects of deformation on the basins described above and on contacts of their cover rock sequences with adjacent pre-Late Ordovician terranes, traversing the area of Figure 3 from southeast to northwest.

Faults separating pre-Late Ordovician and cover sequences have been mapped for several years (e.g., Osberg et al. 1985; Ludman and Berry 2003) but are now also recognized within the cover sequences (Fig. 6). A tectonic overview of relationships in south-central Maine on strike

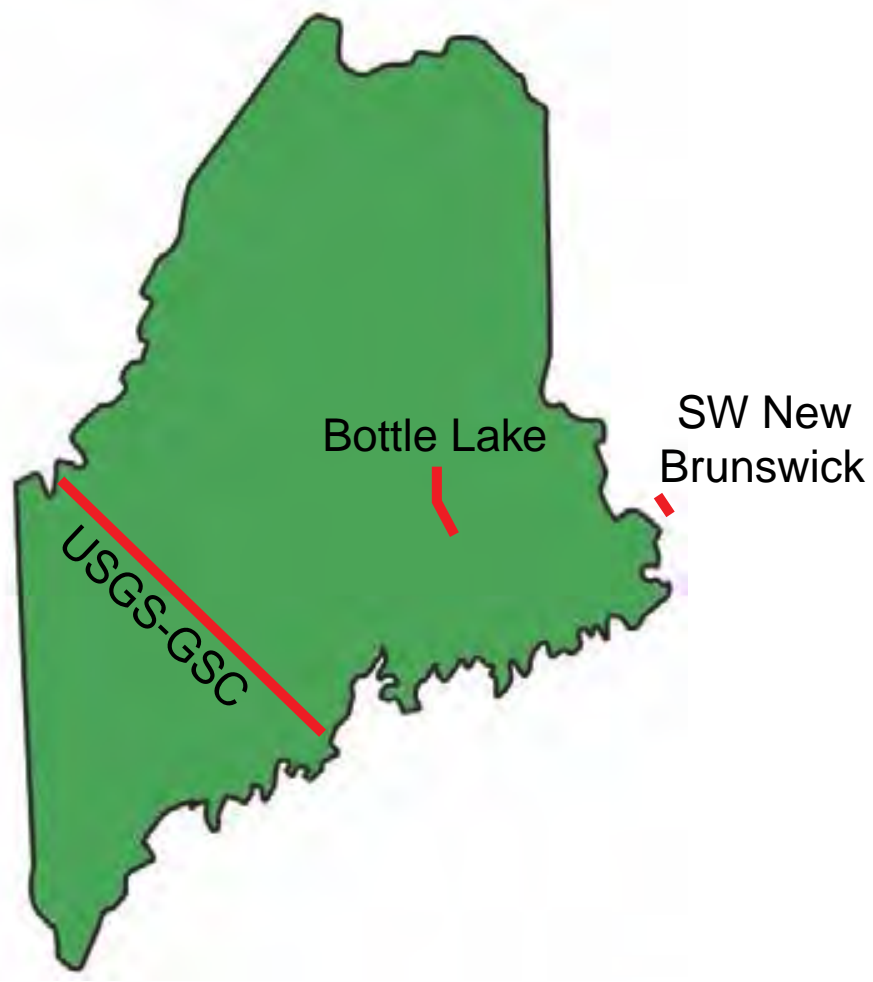

Figure 7. Location of seismic reflection transects discussed in the text. with our study area (Tucker et al. 2001; dashed doublearrow transect in Fig. 2) showed several faults that break stratigraphic continuity in areas previously considered to be continuous sequences or facies transitions (e.g., Ludman and Griffin 1974; Pankiwskyj et al. 1976), and indicated much more telescoping of the cover rocks and their basins than the minimum suggested by Bradley et al. (2000). Some of those structures can be traced to our study area, requiring us to re-examine our previous stratigraphic interpretations. Our interpretations are also informed by three seismic reflection transects that image shallow and mid-crustal structures, some features of which are not expressed at the surface (Figs. 7, 8, 9): the USGS-GSC Global transect (Stewart et al. 1993), the Bottle Lake transect (Doll et al. 1996), and a short proprietary transect in southwestern New Brunswick (Lomas 2012, personal communication).

\section{St. Croix terrane /Fredericton trough boundary}

The pre-Late Ordovician St. Croix terrane was linked to the southeast to the Coastal Volcanic-Mascarene volcanic suite in Silurian time by the Silurian Oak Bay Formation which lies unconformably on the intensely deformed Late Cambrian-Early Ordovician Calais Formation of the St. Croix terrane (Gates 1989; Ludman and Hill 1990). The Oak Bay conglomerate-sandstone sequence in turn passes upward and eastward into Late Silurian volcanic and sedimentary rocks of the Waweig Formation of the Coastal Volcanic-Mascarene suite (Fyffe et al. 1999).

Faults of at least three generations at the northwest boundary of the St. Croix terrane in Maine separate the Kendall Mountain and Woodland formations of the St. Croix terrane from the Digdeguash, and Flume Ridge formations of the Fredericton trough and the Pocomoonshine Lake Formation of uncertain affinity. L. Fyffe (personal communication 2015) described southeast vergent overturned folds in the Digdeguash Formation not observed in our study area. These folds appear to have been early recumbent structures, possibly related to early SEdirected thrusting, later affected by upright folding.

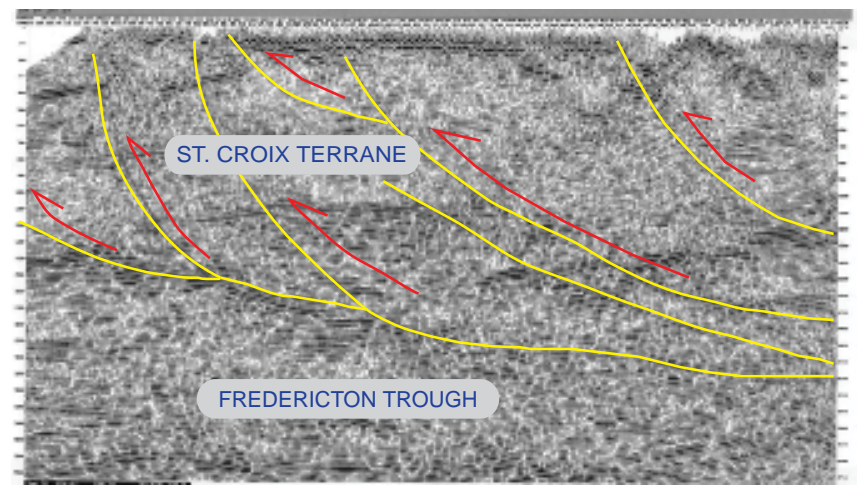

Figure 8. A 5-km-long seismic reflection transect in southwestern New Brunswick near the St. Croix-Fredericton contact. Interpretations from Lomas (personal communication 2012), reproduced by permission. 
West-vergent recumbent folds in the Woodland and Kendall Mountain near the contact with the Digdeguash in Maine suggest that the St. Croix terrane was thrust over the eastern margin of the Fredericton trough on the South Princeton fault (Fig. 6; Ludman and Hill 1986). Recent seismic reflection transects in southwestern New Brunswick just east of the contact support this hypothesis, revealing several west-directed thrust faults in the St. Croix terrane (Figs. 7, 8). These thrusts have apparently buried proximal facies of the Fredericton trough beneath rocks of the allochthonous St. Croix terrane.

The South Princeton fault is in turn cut by the nearvertical Pocomoonshine Lake fault which locally separates St. Croix rocks from the Pocomoonshine pluton (Ludman 1986; Ludman and Berry 2003). In south-central Maine, Tucker et al. (2001) described a similar situation in which the early west-vergent Graham Lake thrust is cut by the Sennebec Pond high-angle fault. In that area, however, it is the Sennebec Pond fault which separates equivalents of the Fredericton and St. Croix belts at the present ground surface in most places. Thrusting on the South Princeton fault was probably a late Salinic/early Acadian event. Fredericton rocks on the lower thrust plate were folded in the Salinic event and before emplacement of the Pocomoonshine pluton at $423 \pm 3 \mathrm{Ma}$ (West et al. 1992; Ludman et al. 2014). The age of the Pocomoonshine Lake fault is uncertain: it cuts and is therefore younger than the Pocomoonshine pluton but there is no constraint on its minimum age.

\section{Deformation in the Fredericton trough}

Strata in the Fredericton trough dip steeply, typically within $15-20^{\circ}$ of vertical and numerous reversals of facing indicators demonstrate significant crustal shortening through small-scale upright isoclinal folds. Unfortunately, the lack of marker horizons makes it impossible to subdivide the Flume Ridge Formation or identify largescale structures. Emplacement of the Pocomoonshine pluton at $423 \pm 3 \mathrm{Ma}$ establishes a Late Silurian (Salinic) age for this deformation, which marks the end of the

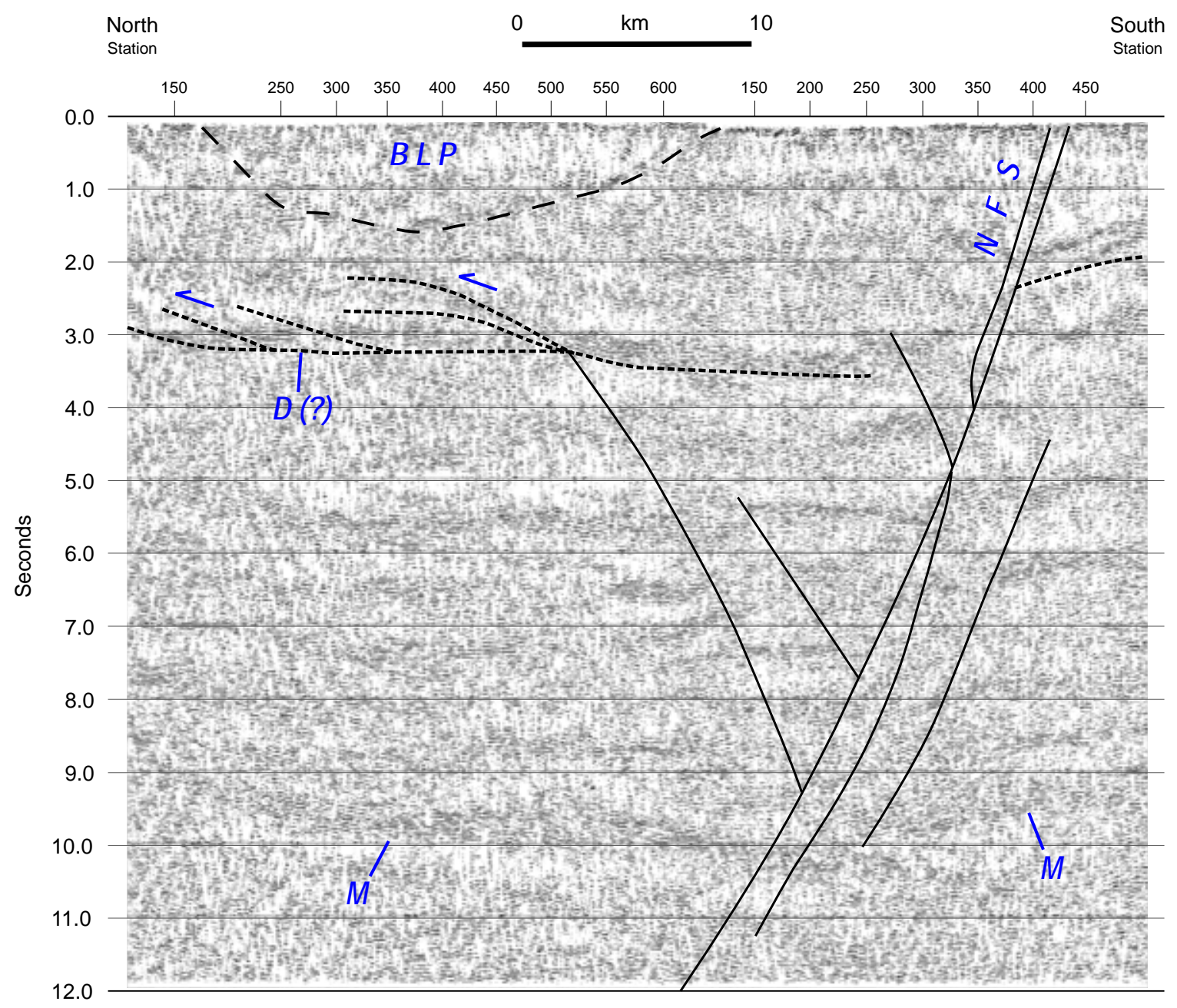

Figure 9. Upper part of Bottle Lake seismic reflection profile. Vertical scale is two-way travel time in seconds. Gently eastdipping reflectors beneath the Bottle Lake pluton (BLP) at 2 to 3 seconds depth are interpreted as northwest-directed blind thrusts above a possible decollement (D). M = Moho; NFS = Norumbega fault system (Waite fault zone). (Modified from Costain et al. 1989). 
Fredericton trough as a depocenter.

An unexpected bonus from the Bottle Lake seismic transect was discovery of southeast-over-northwest blind thrusts possibly associated with a major decollement (Fig. 9) in the Fredericton trough beneath the Bottle Lake pluton (Costain et al. 1989; Doll et al. 1996). These features are similar to those imaged on the SW New Brunswick profile, but are somewhat deeper and do not appear to reach the surface. Bradley et al. (2000) estimated a minimum of 50\% crustal shortening due to Acadian folding, suggested that at least twice that amount was probable, and speculated that shortening could have been much greater just considering the upright folds. Thrust faults imaged in the Bottle Lake transect support that speculation and may also partially explain difficulties in dividing the Flume Ridge into mappable members.

Norumbega fault system The Norumbega fault system is approximately $70 \mathrm{~km}$ wide in eastern Maine and comprises the three high-strain fault zones named in Figure 6 separated by broad zones of distributed weaker strain. The Codyville fault is locally the northwestern boundary of the Fredericton basin (see below), but the Waite and Kellyland faults are intraformational and hosted entirely within the Flume Ridge Formation. Initial ductile shearing began at ca. $380 \mathrm{Ma}$ in all three high-strain strands (Ludman et al. 1999), however Wang and Ludman $(2002,2004)$ identified at least three subsequent mid-to late Paleozoic episodes of reactivation along the central Waite fault zone.

The Norumbega system was once proposed to separate exotic terranes like those of the northwest Cordillera (Kent and Opdyke 1978) but has been shown to have had only $\sim 125 \mathrm{~km}$ of separation (Ludman et al. 1999; West 1999) and clearly does not separate exotic lithostratigraphic blocks in Maine (Ludman 1981; D. West and S. Pollock, personal communication 2015). It and other post-Acadian strikeslip faults in the area of Figure 3 such as the Chester shear zone described by Ludman (2010) and Ghanem et al. (2016) have distorted original basin geometries but do not appear to have grossly altered original geographic or stratigraphic relationships.

\section{Fredericton trough-Miramichi boundary}

The Codyville fault is the northernmost high-strain zone of the Norumbega fault system in eastern Maine and continues into central New Brunswick as the Bamford Brook-Hainesville fault (Fyffe et al. 2011). In easternmost Maine near the New Brunswick border, the Codyville fault separates Miramichi sedimentary rocks from ductilely sheared mylonite derived from Flume Ridge turbidites. The mylonite and eastern components of the Bottle Lake igneous complex (Fig. 3) were subsequently faulted brittlely during an interpreted reactivation of the fault zone. However, only brittle deformation is observed where the Miramichi terrane and Codyville fault emerge from the southwestern margin of the Bottle Lake igneous complex near Greenfield. There, the fault separates Miramichi sedimentary and volcanic rocks and the Smyrna Mills Formation from sandstone of the western facies of the Flume Ridge Formation.

Ductile and brittle fault fabrics indicate initial ductile dextral shearing of Fredericton, Miramichi, and granitic rocks followed by brittle faulting of mylonite, granite, and sedimentary rocks, perhaps with dominantly vertical separation. The Aroostook-Matapedia proximal facies on the western flank of the Miramichi terrane demonstrates that there was an emergent Miramichi highland after Middle Ordovician deformation and prior to deposition of the Late Ordovician to Silurian intermediate and distal facies ( $\mathrm{E}$ and $\mathrm{F}$ in Table 2; Fig. 4). It is difficult to attribute the absence of a cover rock proximal facies southeast of the Miramichi highlands to the two episodes of faulting described above because laterally displaced proximal units have not been identified along the strike of the bounding fault. We suggest that proximal strata of the Fredericton trough were thrust northwestward over their Miramichi source on faults similar to those shown in the seismic profile in Figure 8 prior to the later strike-slip faulting.

\section{Miramichi terrane/Aroostook-Matapedia basin boundary (Stetson Mountain fault)}

The Stetson Mountain fault locally separates the Miramichi terrane from the intermediate and proximal facies of the southeastern lobe of the Aroostook-Matapedia basin, and the extension of the Woodstock-Catamaran fault from New Brunswick (Fyffe et al. 2011) also separates the two belts across strike to the northwest (Fig. 6). On the USGS-GSC seismic transect southwest of the study area (Fig. 7) west-dipping reflectors in the shallow crust were interpreted as east-vergent thrusts at the inferred (buried) southeast flank of the Central Maine basin (Stewart et al. 1993). The Stetson Mountain and Woodstock-Catamaranfaults evolved during a complex series of faulting and folding events, beginning with southeastward thrusting of the Aroostook-Matapedia intermediate facies onto its Miramichi source. Upper and lower thrust plates were then subjected to upright folding during the Salinic/early Acadian orogeny (Ludman 2013). Dip-slip motion on the Stetson Mountain fault then isolated the folded thrust sheet as a klippe (Figs. 3,6) and late-stage strike-slip faulting modified relationships further (Ludman 2013).

\section{Deformation in the Aroostook-Matapedia basin}

Tight to isoclinal upright folds affected all facies of the Aroostook-Matapedia sequence in east-central Maine and transposed layering in Carys Mills and Smyrna Mills strata is axial planar to the dominant folds. Doubly plunging folds involving the Carys Mills, Smyrna Mills, and Madrid formations in the northeastern part of the study area are interpreted as an interference pattern caused by refolding of early recumbent folds by later upright structures. The 
absence of overturned folds in places where bedding can be definitely identified suggests that most of our area lies on an upright limb of the early structures at the present ground surface. The age of these features is constrained by the ages of the affected units: involvement of the Late Silurian-Early Devonian Madrid Formation indicates that both episodes of folding are younger than the Late Silurian deformation in the Fredericton trough. Because Devonian plutons intrude these formations, both episodes of folding are therefore Acadian.

Intrabasinal faults are difficult to recognize in the Aroostook-Matapedia sequence because they potentially juxtapose similar rock types with similar deformation histories. Gently west-dipping cleavage in Carys Mills limestone west of the Miramichi contact and interleaved fault slices of Carys Mills and Sam Rowe Ridge rocks suggest eastward thrusting of distal Aroostook-Matapedia rocks over the intermediate facies after early thrusting now truncated by the Stetson Mountain fault (Ludman 2013).

In addition, two unusual zones of chaotic postlithification disruption up to a few hundred meters wide have been identified in distal Smyrna Mills siltmud turbidites at Passadumkeag and Kingman (Fig. 3). Narrow local zones of disruption are not uncommon in the Smyrna Mills Formation, but three sets of transposed layering with clearly cross-cutting relationships are present in the Kingman zone (Lincoln and Lincoln 1991; Morisi, unpublished data) and two in the Passadumkeag (Ludman, unpublished data), indicating multiple episodes of shearing not seen elsewhere. The timing and significance of these zones are uncertain. They are contained wholly within the Aroostook-Matapedia sequence, in most places close to contacts with the thicker bedded Mayflower Hill sandstone, and may be localized there because of competence contrasts during one or both episodes of Acadian folding.

\section{Central Maine boundary fault (CMBF)/ Chester shear zone}

A tectonic break named the Central Maine boundary fault (CMBF) by Ludman (1983) separates the AroostookMatapedia and Central Maine sequences locally in the Lincoln area in east-central Maine (Figs. 3, 6). The CMBF truncates the Currier Hill syncline and several formations of the Central Maine intermediate facies and juxtaposes them against a belt of Smyrna Mills pelite that can be traced continuously to the Waterville Formation near its type locality in central Maine (Osberg et al. 1985; Ludman 2013).

The current contact drawn as CMBF resulted from a complex sequence of Acadian and post-Acadian events. Distal Central Maine/Aroostook-Matapedia units were initially thrust westward over intermediate units, followed by upright folding attributed to the main phase of the Acadian orogen, and finally by shearing in the kilometerswide Chester shear zone (Ludman 2010). Dominantly dextral shearing in the Chester zone occurred during postAcadian plate adjustments around ca. $380 \mathrm{Ma}$ (Ghanem et al. 2016), coeval with initial activity along the Norumbega fault system to the southeast and the shear fabrics overprint rocks on both upper and lower plates of the original thrust.

Osberg (1988) identified a similar deformation sequence in the Skowhegan - Waterville area southwest of this study area, and suggested a structural explanation for the Central Maine facies relationships shown in Figure 4. There, the east-over-west Lake Messalonskee fault initially thrust a distal unit (Waterville Formation) westward over an intermediate unit (Sangerville Formation). Recumbent folding on both sides of the Lake Messalonskee thrust affected rocks as young as the Late Silurian-Early Devonian Madrid Formation (Tucker et al. 2001) and the thrust itself was subsequently deformed by dominant Acadian upright folding and the Garland fault (Fig. 10). Messalonskee Lake thrusting was therefore an early Acadian event and the upright folding a later phase of that orogeny.

Their similar deformation sequences and timing, lithofacies disruption and juxtaposition, and geographic relationships suggest that the composite, multi-phase $\mathrm{CMBF}$ and Athens thrust/Garland fault complex are connected, as shown in Figure 11.

The recumbent folds and thrusts shown in Figure 10 caused considerable crustal shortening but their effect on the current outcrop patterns of Central Maine and AroostookMatapedia lithofacies cannot be understood fully without more detailed mapping. However, when the recumbent folds are "unfolded" and the thrust sheets restored to their original positions, the interpretation of intermediate and distal facies for the Sangerville and Waterville (= Smyrna Mills), respectively, is still viable.

\section{DISCUSSION}

\section{Paleogeography}

Paleogeographic interpretations of the three postmid-Ordovician stratigraphic sequences discussed above potentially range from deposition in a single basin spanning the entire region to two (Central Maine/Aroostook Matapedia and Fredericton) or three separate basins (Central Maine; Aroostook-Matapedia; Fredericton). Lithofacies evidence and differences in the timing of deformation events indicate the existence of two major depocenters: a separate Fredericton trough in eastern Maine and southwestern New Brunswick, and a single Central Maine/Aroostook-Matapedia (CMAM) basin spanning much of central Maine.

\section{A separate Fredericton depocenter}

Folding that preceded the intrusion of the $423 \mathrm{Ma} \pm 3$ Ma Pocomoonshine pluton indicates that deposition in the Fredericton trough ended by Late Silurian time. In 


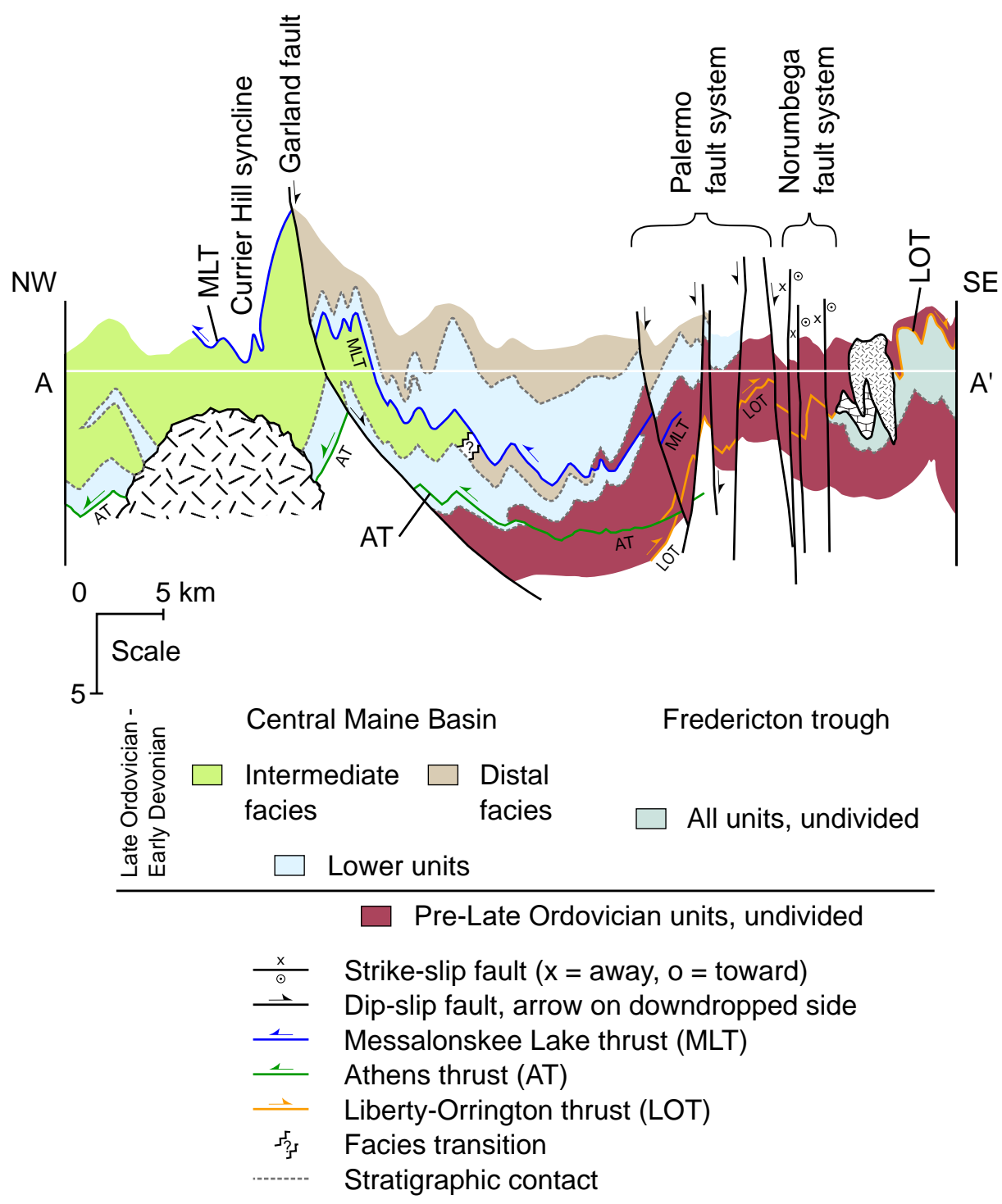

Figure 10. Structural relationships along the Rome-Camden transect (after Tucker et al. 2001). Location of transect shown on Figure 2. Thrust faults: AT = Athens; LOT = Liberty-Orrington; MLT = Messalonskee Lake.

stark contrast, sedimentation continued uninterrupted in the CMAM basin through the Late Silurian (Smalls Falls), and into the Early Devonian (Madrid, Carrabassett, and Seboomook formations). Deposition of the Central Maine and Aroostook-Matapedia sequences did not end until the Acadian deformation front reached central and western Maine in Devonian time (Bradley et al. 2000). In these areas, the Smalls Falls Formation represents the last pre-collisional basin sedimentation, the Madrid the first deposits in the Acadian foreland.

The Cambrian-Ordovician Miramichi terrane was clearly emergent in eastern Maine during Late Ordovician through Silurian time and provided proximal sediment for the Aroostook-Matapedia sequence to the west. A postTaconian/Penobscottian Miramichi highland was thus a local barrier separating the Fredericton trough from depocenters to the northwest. If Acadian and post-Acadian faulting along the Codyville fault have not rearranged relationships drastically, the Miramichi highland would also have been a source of Fredericton trough sediment as suggested by Fyffe (1995). To the southeast, the Fredericton trough is separated from the Silurian Coastal VolcanicMascarene volcanic sequence by the Cambrian-Ordovician St. Croix terrane. The Fredericton trough in eastern Maine and southwestern New Brunswick was therefore an independent basin during Late Ordovician through Middle Silurian times, bounded on the northwest and southeast by highlands and/or islands (Fig. $12 \mathrm{~A}-\mathrm{A}^{\prime}$ ).

The situation may have been different to the southwest, where Fredericton trough strata have been traced to the New Hampshire border as the correlative Appleton Ridge, Bucksport, Kittery, and Eliot formations (Hussey et al. 2010). Today there is not a continuous pre-Late Ordovician terrane like the Miramichi northwest of those units and the Fredericton trough rocks are instead in contact with Central Maine strata, as across the Sunkhaze conceptual 


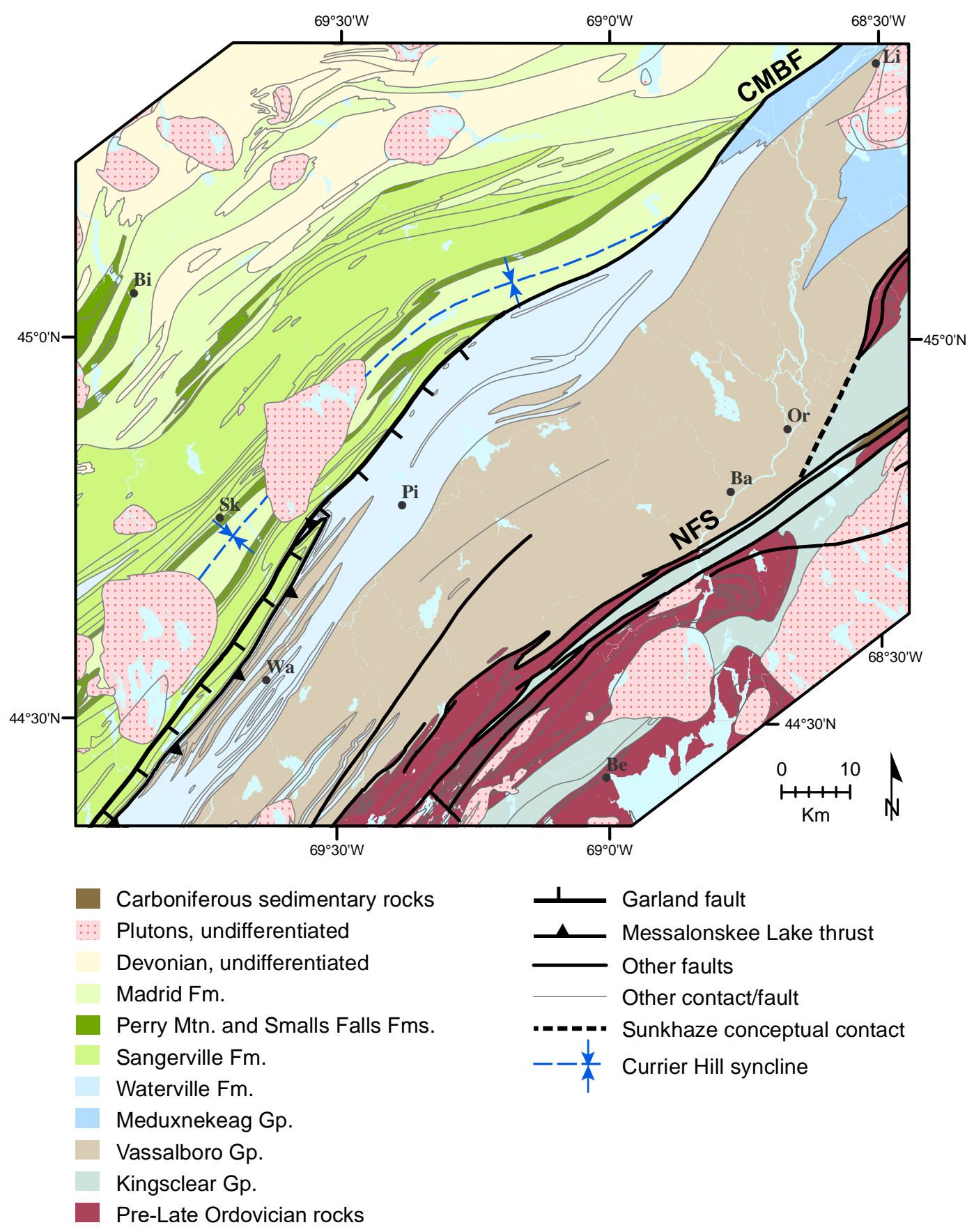

Figure 11. Proposed connection of Messalonskee Lake and Central Maine boundary faults. Compare with Figure 4. Sunkhaze conceptual fault separates sandstones of the Vassalboro and Kingsclear groups east of Orono in an area with little outcrop control. Modified after Osberg et al. (1985); Osberg (1988); Ludman (2010).

fault (Fig. 11). The termination of the Miramichi terrane south of Greenfield is clearly tectonic (Ludman 2014) and thrusting in the Coastal Volcanic sequence may explain its absence there as well.

Several researchers have proposed an emergent Miramichi highland as a source of sediment for the Fredericton trough in southwestern Maine and southeastern New Hampshire. West et al. (2003) suggested that the Casco Bay Group (Fig. 2) is correlative, if not continuous, with the Miramichi terrane, separated from it now by the Norumbega fault system. Wintsch et al. (2007) reported a prominent Ordovician population of detrital zircons in the Berwick Formation probably derived from an emergent Casco Bay/Falmouth-Brunswick terrane. Hussey et al. (2010) suggested a two-sided Fredericton trough derived from both a Miramichi/Falmouth-Brunswick/Casco Bay Group source to the west and a more easterly Gander source, presumably the St. Croix terrane, in Silurian times. 

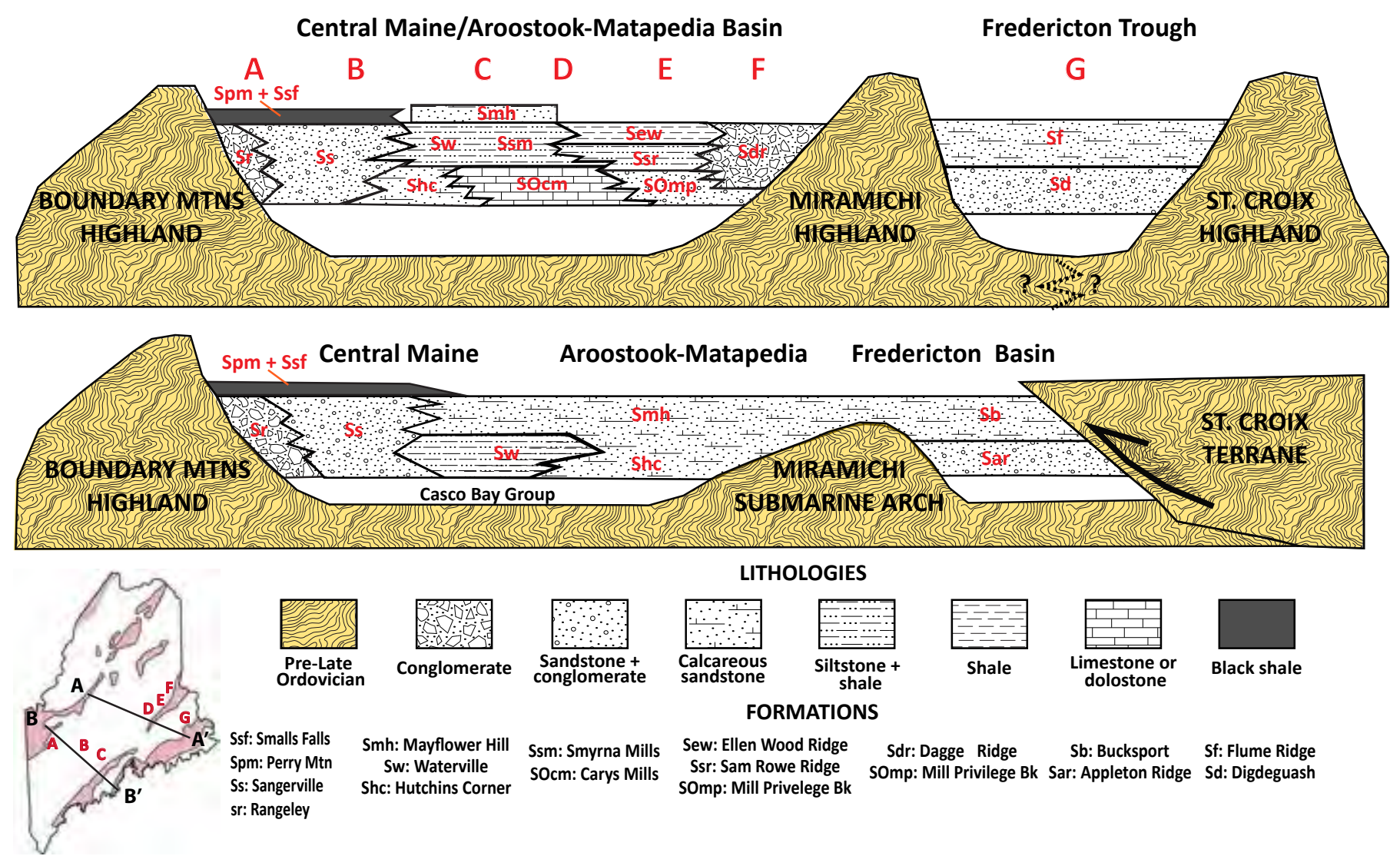

LITHOLOGIES
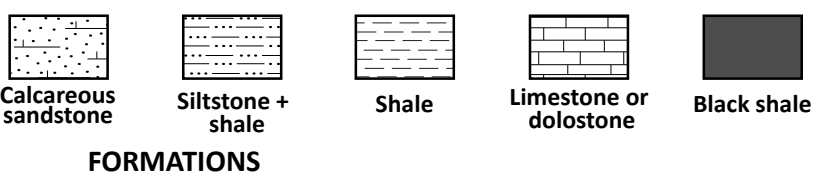

Sew: Ellen Wood Ridge Ssr: Sam Rowe Ridge $\quad$ SOmp: Mill Privilege Bk Sar: Appleton Ridge Sd: Digdeguash SOmp: Mill Privelege Bk

Figure 12. Relationships of Fredericton, Central Maine, and Aroostook-Matapedia depocenters to pre-Silurian sources in Middle-Late Silurian times.

However, Tucker et al. (2001) did not recognize faulting at the contact between Fredericton and CMAM strata in south-central Maine and instead suggested a topographic/ bathymetric explanation for their juxtaposition: the Miramichi belt in south-central Maine may have been a submarine arch rather than an emergent highland, and the Central Maine and Fredericton basins might have merged in southwestern Maine (Fig. 12, section B-B'). This issue remains unresolved and requires further mapping.

\section{A single Central Maine + Aroostook-Matapedia (CMAM) basin}

Several lines of evidence discussed above address relationships of the Central Maine and AroostookMatapedia basins: (1) the Central Maine basin from Rangeley to at least Skowhegan received sediment from the Bronson Hill-Boundary Mountains terrane to the west (2) the western lobe of the Aroostook-Matapedia basin also received sediment from the west, from the MunsungunPennington terrane; (3) our mapping confirms equivalence of the Waterville and Smyrna Mills formations (Fig. 3); (4) sediment of the Waterville Formation in central Maine and the Smyrna Mills and Carys Mills formations in eastcentral and eastern Maine was at least partially derived from the Miramichi belt to the east; and (5) the Mayflower Hill Formation caps both the Waterville Formation of the
"Central Maine basin") and the distal Carys Mills-Smyrna Mills sequence of the Aroostook-Matapedia "basin".

The simplest interpretation is that the Central Maine and Aroostook-Matapedia sequences were deposited in a single large basin flanked by pre-Late Ordovician sediment sources represented today by the Bronson Hill-Boundary Mountains to the west and Miramichi highlands to the east (Fig. 12, A-A'). Today, this CMAM basin is strongly asymmetric, with the western proximal-intermediate-distal distance much greater than the eastern, probably because of eastward thrusting of Aroostook-Matapedia rocks described earlier.

Recognition of major recumbent folds in the axial region of the proposed CMAM in central and northeastern Maine suggests that the simplest explanation may not be the best. At the very least, these early structures show that the CMAM was much wider than previously inferred. In addition, the discovery that stratigraphic continuity is broken by the Lake Messalonskee thrust and CMBF raises suggests additional complexities. These faults have disturbed original lithofacies relationships, telescoped basin fill significantly, and juxtaposed rocks not originally deposited next to one another. However, while these events have shuffled relationships, they do not necessarily invalidate the pre-deformation facies interpretations shown in Figure 12. 


\section{Regional paleogeography}

Neuman (1967) reported that basal Silurian conglomerate on the southeast flank of the Weeksboro-Lunksoos Lake terrane contains clasts derived from the CambrianOrdovician section below the Taconian unconformity. Hall (1970) described similar relationships on the southwestern margin of the Munsungun-Pennington terrane to the north. These sedimentary linkages demonstrate that, like the Miramichi and Bronson Hill-Boundary Mountains, the Munsungun and Weeksboro-Lunksoos Lake preSilurian tracts were emergent after the Taconian orogeny. Interestingly, proximal facies are found on only one flank of these belts, a situation also similar to that of the Miramichi terrane, suggesting similar histories of local thrusting at one of their margins. Based on detrital zircon age populations, the Connecticut Valley-Gaspé basin in northwestern Maine and the Gaspé Peninsula of Quebec received sediment from both northwestern and southeastern sources (McWilliams et al. 2010).

Shallow-water shelly fauna characterize the proximal facies flanking the St. Croix, Miramichi, WeeksboroLunksoos Lake, and Munsungun highlands. In contrast, fossils are extremely rare in the more distal basin sediments; the few present are typically a graptolite fauna. This difference, coupled with the turbidite bedding of the basin deposits, suggests relatively rapid transitions from the pre-Late Ordovician source areas to a deep-water environment. Carys Mills limestone in the AroostookMatapedia sequence interfingers locally with siliciclastic and volcaniclastic sediments derived from the adjacent Miramichi, Weeksboro-Lunksoos Lake, and MunsungunPennington belts (Hall 1970; Pavlides 1968). The limestone is thought to have been derived from the shallow water Laurentian platform (Fyffe et al. 2011) and appears to have been transported by axial currents into deeper water in troughs separating the three highlands (Fig. 13).

Figure 13 summarizes our interpretation of preDevonian paleogeography based on the current extent of the cover sequences. Strike-parallel gaps between source regions reflect the current boundaries of the CambrianOrdovician belts but their subaerial extent during the Late Ordovician and Early Silurian is unknown and is obscured by complex faulting, particularly in south-central Maine.

Initial results from a pilot study of detrital zircons in the study area confirm an internal Ganderian source for Silurian sandstone of the Fredericton, Aroostook-Matapedia, and Central Maine sequences (Ludman et al. 2014; Berry et al. 2014). Similar results, including a population of Silurian zircons, have been reported for the proximal facies of the CMAM basin (Bradley and O'Sullivan 2016) and the Fredericton trough in New Brunswick (Waldron, personal communication 2015). A possible Avalonian source is suggested by detrital zircons with ages of $500-740 \mathrm{Ma}$ in some Fredericton and CMAM sandstone units, and all samples in the pilot study contain zircons of $1.0-1.35 \mathrm{Ga}$ age (Ludman et al. 2014; Berry et al. 2014). Although it is tempting to attribute these older zircons to a Grenvillian (i.e., Laurentian) source, Bradley et al. (2000) have demonstrated that similar ages can be found in West Africa and other areas. All samples have a Grenvillian component $(1.0-1.35 \mathrm{Ga})$ and some Fredericton and AroostookMatapedia samples also have a possible Avalonian signature (ca. 500-740 Ma). These data suggest that the post-Taconian highlands were not continuous barriers to sediment transport from either northwest or southeast, and that the gaps in Figure 13 may have been real.

Bradley et al. (2000) suggested that the basins exposed today have been telescoped to $50 \%$ of their original widths and perhaps closer to $30 \%$. This estimate did not take into account the recumbent folding now recognized in the CMAM basin, nor the overthrusting of the St. Croix terrane over the Fredericton trough. If additional intrabasinal thrusts and high-angle reverse faults postulated in the Tucker et al. (2001) tectonic model are correct, the CMAM basin, currently about $160 \mathrm{~km}$ wide, would probably have been more than five times wider.

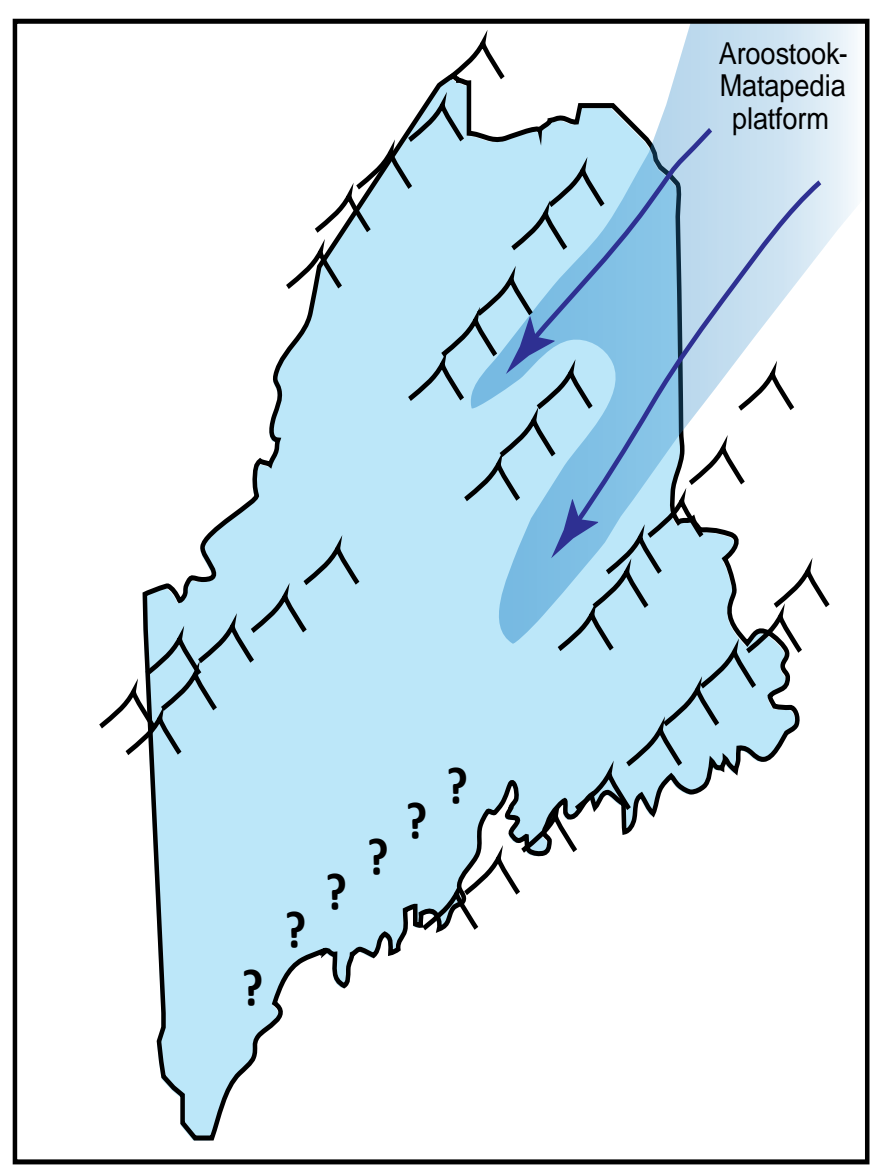

Figure 13. Interpreted paleogeography between post-Taconian and Acadian tectonism. The shading gradient highlights increasing depth of Aroostook-Matapedia deposition to the southwest. Arrows indicate inferred axial currents. 


\section{Origin of the post-Late Ordovician, pre-Devonian basins}

Lithofacies relationships adjacent to the CambrianOrdovician highlands shown in Figure 13 indicate that the depocenters described in this paper existed immediately after the Taconian orogeny and continued to receive sediment from post-Taconian highlands until the Late Silurian in the case of the Fredericton trough, and through the Early Devonian in the CMAM and Connecticut ValleyGaspé basins. These depocenters are thus older than the Acadian foreland basin recognized by Bradley et al. (2000), and were most likely produced by a combination of Taconian deformation and post-Taconian extensional plate adjustments as suggested by Tremblay and Pinet (2005) and Rankin et al. 2007).

\section{Role of Cambrian-Ordovician terranes in Acadian deformation}

The presence of faults at most cover rock/"basement block" contacts suggests that the pre-Silurian blocks played a role in localizing brittle Acadian and postAcadian deformation. This role may have been creating a local competence contrast between rapidly deposited water-rich basin fill and previously deformed rocks partly dehydrated by low-grade regional metamorphism. It might also have been interaction among the crustal blocks whose amalgamation created Ganderia, some perhaps buried today beneath the cover strata. Unfortunately, the lack of seismic profiles across the basins leaves the subsurface extent and geometries of those blocks uncertain.

Field and seismic reflection evidence suggest that the Miramichi and St. Croix terranes played different roles during Acadian deformation. Thrusting of AroostookMatapedia and Fredericton cover rocks onto the Miramichi, from northwest and southeast respectively, implies that the Miramichi acted as a buttress during Late Silurian Salinic through Early Devonian Acadian deformation. In contrast, the St. Croix terrane was apparently thrust over the Fredericton sequence and is at least parautochthonous locally, if not allochthonous.

\section{CONCLUSIONS}

1. Late Ordovician through Silurian paleogeography in Maine and adjacent Quebec and New Brunswick was shaped by plate adjustments following the initial accretion of the Ganderian composite plate to Laurentia in Middle to Late Ordovician time (i.e., the Taconic orogeny).

2. Late Ordovician through Silurian topography comprised islands and more continuous highlands separated by broad deep-water basins. Those landmasses are represented today by the Cambrian-Ordovician components of Ganderia, and the basins by the post-Late Ordovician sediments of the Fredericton, AroostookMatapedia, and Central Maine sequences.
3. Preserved lithofacies patterns indicate that the Cambrian-Ordovician terranes were emergent and provided at least part of the sediment of the thick (largely Silurian) cover rock sequences but Acadian and postAcadian faulting have obscured lithofacies relationships in several areas.

4. Detailed relationships summarized above indicate that, in Silurian time, the study area in eastern and east-central Maine contained two distinct depocenters separated by an emergent Miramichi terrane: one (CMAM) in which the Central Maine and Aroostook-Matapedia sequences were deposited and a second in which the Kingsclear Group of the Fredericton sequence formed. Uncertainty about the southwestward extent of the Miramichi highland makes it possible that the two major depocenters merged in what is now southern Maine.

5. The two lobes underlain by the Aroostook-Matapedia sequence were troughs in which carbonate sediment was transported by axial currents into deeper regions to the southwest. The gradual southwestward decrease and eventual disappearance of Aroostook-Matapedia carbonate is attributed to increasing distance from the source coupled with a greater proportion of siliciclastic sediment from bordering highlands.

6. This sedimentary regime ended in the Late Silurian with the onset of Salinic deformation which destroyed the Fredericton trough. It was followed by development of an Acadian forebulge and foredeep which migrated northwestward from coastal Maine through the study area until the Middle Devonian. Sediment from local highlands was then replaced uniformly by debris derived from the forebulge to the east.

7. Salinic and Acadian deformation included an early phase of recumbent folding, thrusting, upright tight to isoclinal folding, and high-angle normal, reverse, and strike-slip faulting. Recumbent folding and thrusting are more widespread than previously thought, and caused significant crustal shortening. The CMAM basin alone discussed in this paper is estimated have been greater than $800 \mathrm{~km}$ wide.

8. The Miramichi terrane appears to have acted as a buttress during Acadian deformation but the St. Croix terrane seems to have been at least somewhat allochthonous, thrust westward over the eastern part of the Fredericton trough.

\section{ACKNOWLEDGMENTS}

The Maine Geological Survey has supported our field work throughout much of the past three decades, with additional funding from the USGS EdMap and StateMap programs. We are grateful to Maine State Geologists Robert Doyle, Walter Anderson and Robert Marvinney for their enthusiastic interest and encouragement, and to Amber Whittaker for drafting several of the final maps and figures. Ludman's early work in eastern Maine was partially funded 
by PSC-CUNY and NSF research awards. Conversations with Robert Marvinney, Steven Pollock, Chunzeng Wang, and Robert Wintsch have been most helpful. We are grateful to Wallace Bothner, Dwight Bradley, and John Waldron for their thoughtful comments on earlier versions of this manuscript and to editor David West and two anonymous reviewers for suggestions that improved the final product substantially.

\section{REFERENCES}

Berry, H., IV., Aleinikoff, J., Ludman, A., and Hopeck, J. 2014. U-Pb geochronology of detrital zircon in Silurian sandstones of eastern Maine: A glimmer of hope. Geological Association of CanadaMineralogical Association of Canada Abstracts, 37, p. 26-27.

Bird, J. and Dewey, J. 1970. Lithosphere plate-continental margin tectonics and the evolution of the Appalachian orogen. Geological Society of America Bulletin, 81, pp. 1031-1060. https://doi.org/10.1130/00167606(1970)81[1031:LPMTAT]2.0.CO;2

Bradley, D. 1983. Tectonics of the Acadian orogeny in New England and adjacent Canada: Journal of Geology, 91, no. 4, pp. 381-400. https://doi.org/10.1086/628785

Bradley, D. and O'Sullivan, P. 2016. Detrital zircon geochronology of pre-and syn-collisional strata, Acadian orogen, Maine Appalachians. Basin Research (on-line version). https://doi.org/10.1111/bre.12188

Bradley, D. Tucker, R. Lux, D. Harris, A., and McGregor, D. 2000. Migration of the Acadian orogen and foreland basin across the Northern Appalachians of Maine and adjacent areas; United States Geological Survey Professional Paper 1624, $51 \mathrm{p}$.

Costain, J. Domoracki, W., and Coruh, C. 1989. Processing and preliminary interpretation of the Bottle Lake seismic reflection data. Final report. Maine Geological Survey Open File report, 28 p.

Doll, W. Domoracki, J. Costain, J. Coruh, C, Ludman, A., and Hopeck, J. 1996. Seismic reflection evidence for the evolution of a transcurrent fault system: Norumbega fault zone, Maine. Geology 24, pp. 252-254. https:// doi.org/10.1130/0091-7613(1996)024<0251:SREFTE> 2.3.CO;2

Fyffe, L.R. 1995. Fredericton belt. In Chapter 4 of the Geology of the Appalachian-Caledonian Orogen in Canada and Greenland. Edited by H. Williams. Geological Survey of Canada, Geology of Canada 6, pp. 351-354.

Fyffe, L.R. 2005. Bedrock geology of the St. Stephen area (NTS 21G/3), Charlotte County New Brunswick, New Brunswick Department of Natural Resources and Energy; Minerals, Policy and Planning Division, MP 2005-28, scale 1:50 000.
Fyffe, L., Johnson, S., and van Staal, C. 2011. A review of Proterozoic to Early Paleozoic lithotectonic terranes in the northeastern Appalachian orogen of $\mathrm{New}$ Brunswick, Canada, and their tectonic evolution during Penobscot, Taconic, Salinic, and Acadian orogenesis. Atlantic Geology, 47, pp. 211-248. https:// doi.org/10.4138/atlgeol.2011.010

Fyffe, L., Pickerill, R., and Stringer, P. 1999. Stratigraphy, sedimentology and structure of the Oak Bay and Waweig formations, Mascarene Basin; implications for the paleotectonic evolution of southwestern New Brunswick. Atlantic Geology, 35, pp. 59-84. https:// doi.org/10.4138/2024

Gates, O. 1989. Silurian roundstone conglomerates of coastal Maine and adjacent New Brunswick. In Studies in Maine Geology: Volume 2 - Structure and Stratigraphy. Edited by R. Tucker and R. Marvinney. Maine Geological Survey (Department of Conservation), p. 127-144.

Ghanem, H., Kunk, M., Ludman, A., and Wintsch, R. 2016. Dating slate belts using ${ }^{40} \mathrm{Ar} /{ }^{39} \mathrm{Ar}$ geochronology and zircon ages from crosscutting plutons: A case study from east-central Maine, USA. Journal of Structural Geology, 93, pp. 51-66. https://doi.org/10.1016/j. jsg.2016.10.004

Hall, B. 1970. Stratigraphy of the southern end of the Munsungun anticlinorium, Maine. Maine Geological Survey Bulletin 22, Augusta, Maine, 63 p.

Hatcher, R. 2010. The Appalachian orogen: A brief summary. In From Rodinia to Pangea: The lithotectonic record of the Appalachian region. Edited by R. Tollo, M. Bartholomew, J. Hibbard, and P. Karabinos. Geological Society of America Memoir 206, pp.1-19.

Hibbard, J., van Staal, C., and Rankin, D. 2010. Comparative analysis of the geologic evolution of the northern and southern Appalachian orogen: Late Ordovician-Permian. In From Rodinia to Pangea: The lithotectonic record of the Appalachian region. Edited by R. Tollo, M. Bartholomew, J. Hibbard, and P. Karabinos. Geological Society of America Memoir 206, pp. 51-69.

Hibbard, J., van Staal, C., Rankin, D., and Williams, H. 2006. Lithotectonic map of the Appalachian orogen, Canada-United States of America. Geological Survey of Canada, Map 2096, scale 1:1 500000.

Hopeck, J. 1994. Post-Caradocian strata of the Miramichi anticlinorium and their relation to the AroostookMatapedia belt. In Guidebook to field trips in northcentral Maine. Edited by L. Hanson. New England Intercollegiate Geological Field Conference 1994 Guidebook, pp. 1-17.

Hopeck, J. 1998. Stratigraphy and structural geology of the Wytopitlock and Springfield fifteen-minute quadrangles, eastern Maine; Unpublished $\mathrm{PhD}$ dissertation; City University of New York, New York, $160 \mathrm{p}$. 
Hopeck, J. 2013. Transitional relationships in the Miramichi, Aroostook-Matapedia, and Central Maine belts. In Guidebook for field trips in north-central Maine. Edited by L. Hanson. New England Intercollegiate Geological Conference Trip C-3, pp. 209-214.

Hussey, A. II, Bothner, W., and Aleinikoff, J. 2010. The tectonostratigraphic framework and evolution of southwestern Maine and southeastern New Hampshire. In From Rodinia to Pangea: The lithotectonic record of the Appalachian region. Edited by R. Tollo, M. Bartholomew, J. Hibbard, and P. Karabinos. Geological Society of America Memoir 206, pp. 205-230.

Kent, D. and Opdyke, N. 1978. Paleomagnetism of the Devonian Catskill red beds: Evidence for motion of the coastal New England-Canadian maritime region relative to cratonic North America. Journal of Geophysical Research: Solid Earth 83, B9, pp. 44414450. https://doi.org/10.1029/JB083iB09p04441

Larrabee, D., Spencer, C., and Swift, D. 1965. Bedrock geology of the Grand Lake area, Aroostook, Hancock, Penobscot, and Washington counties, Maine. United States Geological Survey Bulletin 1201-E, 38 p.

Llamas, A. and Hepburn, J. 2013. Geochemistry of SilurianDevonian volcanic rocks in the Coastal Volcanic belt, Machias-Eastport area, Maine: Evidence for a preAcadian arc. Geological Society of America Bulletin 125, pp. 1930-1942. https://doi.org/10.1130/B30776.1

Ludman, A. 1969. Geology of the Skowhegan quadrangle, Maine. Unpublished Ph.D. thesis, University of Pennsylvania, Philadelphia, Pennsylvania, 230 p.

Ludman, A. 1976. A fossil-based stratigraphy in the Merrimack Synclinorium, central Maine. In Contributions to New England Stratigraphy. Edited by L. Page. Geological Society of America Memoir 148, pp. 65-78. https://doi.org/10.1130/MEM148-p65

Ludman, A. 1981. Significance of transcurrent faulting in eastern Maine and location of the suture between Avalonia and North America. American Journal of Science, 281, pp. 463-483. https://doi.org/10.2475/ ajs.281.4.463

Ludman, A. 1983. Geology of eastern and east-central Maine; unpublished compilation map incorporated in the Osberg et al. (1985), Bedrock Geologic Map of Maine. Geological Survey, Augusta, Maine, scale 1:500 000.

Ludman, A. 1986. Bedrock geology of the Big Lake 15' Quadrangle, eastern Maine. Maine Geological Survey Open File Report OF 86-1, 44 p and 1:62 500-scale map.

Ludman, A. 1991. Revised stratigraphy of the Cookson Group (St. Croix terrane), eastern Maine and southwestern New Brunswick. In Geology of the Coastal Lithotectonic Block and neighboring terranes, eastern Maine and southern New Brunswick. Edited by A. Ludman. New England Intercollegiate Geological Conference Guidebook, pp.114-132.
Ludman, A. 2010. The Chester shear zone: Nature and tectonic significance of kilometers-wide chaos in eastcentral Maine. In Guidebook for field trips in coastal and interior Maine. Edited by C. Gerbi, M. Yates, A. Kelley, and D. Lux. New England Intercollegiate Geological Field Conference Guidebook, pp. A2 1-17.

Ludman, A. 2013. Closing the gap: Relationships of the Waterville and Aroostook-Matapedia sequences. In Guidebook for field trips in north-central Maine. Edited by L. Hanson. New England Intercollegiate Geological Conference, pp. 1-14.

Ludman, A. 2014. Bedrock geology of the Greenfield quadrangle, Maine. Maine Geological Survey Open File Report, $30 \mathrm{p}$ and 1:24 000-scale map.

Ludman, A. and Berry, H. 2003, Bedrock Geologic Map of the Calais 1:100 000 quadrangle. Maine Geological Survey, Open File Map 03-97, scale 1:100 000.

Ludman, A. and Griffin, J. 1974. Geology of central Maine. In Guidebook for trips in south-central and eastcentral Maine. Edited by P. Osberg. New England Intercollegiate Geological Conference, pp. 154-179.

Ludman, A. and Hill, M. 1986. Bedrock geology of the Calais 15' quadrangle, eastern Maine. Maine Geological Survey Open File Report 86-72, 54 p and 1:62 500-scale map.

Ludman, A. and Hill, M. 1990. Bedrock geology of the Calais 15' Quadrangle, eastern Maine. Maine Geological Survey, Open File 90-27, 32 p.

Ludman, A. and Hopeck, J. 2011. Tectonic implications of a revised bedrock geologic map of east-central Maine. Geological Society of America Abstracts with programs, 43, No.1, p. 160.

Ludman, A. and West, D. Jr. (Editors). 1999. Norumbega fault system of the Northern Appalachians. Geological Society of America Special Paper 331, 202 p.

Ludman, A. Aleinikoff, J. Hopeck, J., and Berry, H. I 2014. SHRIMP U-Pb geochronology of pre-Acadian Silurian basins of central and east-central Maine and the Pocomoonshine pluton: Diverse sources, rapid sedimentation, tectonism and intrusion. Geological Society of America Abstracts with Programs, 46, p. 122.

Ludman, A. Lanzirotti, A. Lux, D., and Wang, C. 1999. Constraints on timing and displacement of multistage shearing in the Norumbega fault system, eastern Maine. In Norumbega fault system of the Northern Appalachians. Edited by A. Ludman and D. West Jr. Geological Society of America Special Paper 331, pp. 179-194. https://doi.org/10.1130/0-8137-2331-0.179

Marvinney, R. West, D. Jr. Grover, T., and Berry, H. 2010. A stratigraphic review of the Vassalboro Group in a portion of central Maine. In Guidebook for field trips in coastal and interior Maine. Edited by C. Gerbi, M. Yates, A. Kelley, and D. Lux. New England Intercollegiate Geological Conference Guidebook. pp 61-76. 
McWilliams, C. Walsh, G., and Wintsch, R. 2010. SilurianDevonian age and tectonic setting of the Connecticut Valley-Gaspé trough in Vermont based on U-Pb SHRIMP analyses of detrital zircons. American Journal of Science, 310, pp. 325-363. https://doi. org/10.2475/05.2010.01

Moench, R. 1971. Geologic map of the Rangeley and Phillips15-minute quadrangles, Franklin and Oxford Counties, Maine. United States Geological Survey, Miscellaneous Geologic Investigations Map, I-605, scale 1:62 500 .

Moench, R. and Pankiwskyj, K. A. 1988. Geologic map of western interior Maine, with contributions by G. Boone, E. Boudette, A. Ludman, W.R. Newell, and T. Vehrs. United States Geological Survey, Miscellaneous Investigations Map I-1692, scale 1:250 000.

New Brunswick Department of Natural Resources and Energy. 2000. Bedrock Geology of New Brunswick. Minerals and Energy Division Map NR-1, scale 1:500 000.

Neuman, R. 1967. Bedrock geology of the Shin Pond and Stacyville quadrangles, Penobscot County, Maine. United States Geological, Survey Professional Paper 524-I. $37 \mathrm{p}$.

Osberg. P. 1968. Stratigraphy, structural geology, and metamorphism of the Waterville-Vassalboro area, Maine. Maine Geological. Survey Bulletin, 20, 64 p.

Osberg, P. 1978. Synthesis of the geology of the northeastern Appalachians, U.S.A. In Caledonian-Appalachian orogen of the North Atlantic region: Geological Survey of Canada, Paper 78-13, pp. 137-147.

Osberg, P. 1988. Geologic relations within the shale-wacke sequence in south-central Maine. Maine Geological Survey, Studies in Maine Geology 1, pp. 51-73.

Osberg, P. Hussey, A. II, and Boone, G. 1985. Bedrock Geologic Map of Maine. Maine Geological Survey, Augusta, Maine, scale 1:500 000.

Osberg, P., Tull, J., Robinson, P., Hon, R., and Butler, J. 1989. The Acadian orogeny. In The Appalachian-Ouachita Orogen in the United States, The Geology of North America, Chapter 4. Edited by R. Hatcher, W. Thomas, and G. Viele. Geological Society of America, F-2, pp. 179-232.

Pankiwskyj, K., Ludman, A., Griffin, J., and Berry, W. 1976. Stratigraphic relationships on the southeast limb of the Merrimack Synclinorium in central and west-central Maine. In Studies in New England Geology. Edited by A. Brownlow and P. P. Lyons. Geological Society of America Memoir 146, pp. 263-280.

Pavlides, L. 1968. Stratigraphic and facies relationships of the Carys Mills Formation of Ordovician and Silurian age, northeastern Maine. United States Geological Survey Bulletin 1264. 44 p.

Pavlides L. 1971. Geologic map of the Houlton quadrangle. United States Geological Survey GQ-920, scale 1:62 500 .
Pavlides, L. 1974. General bedrock geology of northeastern Maine. In Geology of east-central and northcentral Maine. Edited by P. P. Osberg. New England Intercollegiate Geological Conference, pp. 61-84.

Rankin, D., Coish, R. Tucker, R.., Peng, Z. Wilson, S., and Rouff, A. 2007. Silurian extension in the upper Connecticut Valley, United States and the origin of middle Paleozoic basins in the Quebec Embayment. In John Rodgers memorial issue; Part I. Edited by R. Wintsch. American Journal of Science, 307, pp. 216264.

Reusch, D. and van Staal, C. 2012. The Dog Bay - Liberty Line and its significance for Silurian tectonics of the northern Appalachian orogen. Canadian Journal of Earth Sciences, 49, p. 239-258.

Ruitenberg, A., and Ludman, A., 1978. Stratigraphy and tectonic setting of early Paleozoic sedimentary rocks of the Wirral-Big Lake area, southwestern New Brunswick and southeastern Maine. Canadian Journal of Earth Sciences, 15, pp. 22-32. https://doi.org/10.1139/e78002

Stewart, D. Wright, B. Unger, J. Phillips, J., and Hutchinson, D. 1993. Global Geoscience transect 8: QuebecGulf of Maine Transect, southeastern Canada, and northeastern United States of America. US Geological Survey to accompany Map I-2329 $17 \mathrm{p}$ and 1:1 000 000-scale map

Tremblay, A. and Pinet, N. 2005. Diachronous supracrustal extension in an intraplate setting and the origin of the Connecticut Valley-Gaspé and Merrimack troughs, northern Appalachians. Geological Magazine, 142, pp. 7-22. https://doi.org/10.1017/S001675680400038X

Tucker, R., Osberg, P., and Berry, H. 2001. The Geology of a part of Acadia and the nature of the Acadian orogeny across central and eastern Maine. American Journal of Science, 301, pp. 205-260.

van Staal, C. 1994. Brunswick subduction complex in the Canadian Appalachians: record of the Late Ordovician to Late Silurian collision between Laurentia and the Gander margin of Avalon. Tectonics, 13, pp. 946-962. https://doi.org/10.1029/93TC03604

van Staal, C., Whalen, J., Valverde-Vaquero, P., Zagorevski, A., and Rogers, N. 2009. Pre-Carboniferous, episodic accretion-related, orogenesis along the Laurentian margin of the northern Appalachians. In Ancient Orogens and Modern Analogues. Edited by J. Murphy, J. Keppie, and A. Hynes. Geological Society of London, Special Publications 327, pp. 271-316. https://doi. org/10.1144/SP327.13

Wang, C. and Ludman, A. 2002. Evidence for post-Acadian through Alleghanian deformation in eastern Maine: multiple brittle reactivation of the Norumbega fault system. Atlantic Geology 38, p. 37-52.

Wang, C. and Ludman, A. 2004. Deformation conditions, kinematics, and displacement history of shallow crustal ductile shearing in the Norumbega fault 
system in the Northern Appalachians, eastern Maine. Tectonophysics, 384, pp. 129-148. https://doi. org/10.1016/j.tecto.2004.03.013

West, D. Jr. 1999. The timing of displacements along the Norumbega fault system, south-central and southcoastal Maine. In Norumbega fault system of the Northern Appalachians. Edited by A. Ludman and D. West, Jr. Geological Society of America Special Paper, 331, pp. 167-178. https://doi.org/10.1130/0-81372331-0.167

West, D. Jr. and Roden-Tice, M. 2003. Late Cretaceous reactivation of the Norumbega fault zone, Maine: Evidence from apatite fission-track ages. Geology, 31, pp. 649-652. https://doi.org/10.1130/00917613(2003)031<0649:LCROTN>2.0.CO;2

West, D. Jr., Ludman, A., and Lux, D. 1992. Silurian age for the Pocomoonshine gabbro-diorite, southeastern Maine, and its tectonic implications. American Journal of Science 292, pp. 253-273. https://doi.org/10.2475/ ajs.292.4.253
West, D. Jr, Beal, H. M., and Grover, T.W. 2003. Silurian deformation and metamorphism of Ordovician arc rocks of the Casco Bay Group, south-central Maine. Canadian Journal of Earth Sciences, 40, pp. 887-905. https://doi.org/10.1139/e03-021

Westerman, D. 1978. Bedrock geology of the Wesley quadrangle. In New England Intercollegiate Geological Conference, Guidebook for fieldtrips in southeastern Maine and southwestern New Brunswick. Edited by A. Ludman. Queens College Geological Bulletin No. 6, pp. 120-132.

Wintsch, R., Aleinikoff, J., Walsh, G., Bothner, W., Hussey, A. II, and Fanning, C. 2007. SHRIMP U-Pb evidence for a Late Silurian age of metasedimentary rocks in the Merrimack and Putnam-Nashoba terranes, eastern New England. In John Rodgers Memorial Issue Part 1. Edited by R. Wintsch. American Journal of Science, 307, pp. 119-167.

Editorial responsibility: David P. West, Jr. 